\title{
Retinoic Acid Receptor RAR $\alpha$-Dependent Synaptic Signaling Mediates Homeostatic Synaptic Plasticity at the Inhibitory Synapses of Mouse Visual Cortex
}

\author{
ㄴei R. Zhong, ${ }^{1}$ Xin Chen, ${ }^{1}$-Esther Park, ${ }^{1}$ Thomas C. Südhof, ${ }^{2}$ and ${ }^{\circ}$ Lu Chen ${ }^{1}$ \\ ${ }^{1}$ Department of Neurosurgery, Department of Psychiatry and Behavioral Sciences, and ${ }^{2}$ Howard Hughes Medical Institute, Department of Molecular and \\ Cellular Physiology, Stanford University School of Medicine, Stanford, California 94305-5453
}

\begin{abstract}
Homeostatic synaptic plasticity is a synaptic mechanism through which the nervous system adjusts synaptic excitation and inhibition to maintain network stability. Retinoic acid (RA) and its receptor RAR $\alpha$ have been established as critical mediators of homeostatic synaptic plasticity. In vitro studies reveal that RA signaling enhances excitatory synaptic strength and decreases inhibitory synaptic strength. However, it is unclear whether RA-mediated homeostatic synaptic plasticity occurs in vivo, and if so, whether it operates at specific types of synapses. Here, we examine the impact of RA/RAR $\alpha$ signaling in the monocular zone of primary visual cortex $(\mathrm{V} 1 \mathrm{~m})$ in mice of either sex. Exogenous RA treatment in acute cortical slices resulted in a reduction in mIPSCs of layer $2 / 3$ pyramidal neurons, an effect mimicked by visual deprivation induced by binocular enucleation in postcritical period animals. Postnatal deletion of RAR $\alpha$ blocked RA's effect on mIPSCs. Cell type-specific deletion of RAR $\alpha$ revealed that RA acted specifically on parvalbumin (PV)-expressing interneurons. RAR $\alpha$ deletion in $\mathrm{PV}^{+}$interneurons blocked visual deprivation-induced changes in mIPSCs, demonstrating the critical involvement of RA signaling in $\mathrm{PV}^{+}$interneurons in vivo. Moreover, visual deprivation- or RA-induced downregulation of synaptic inhibition was absent in the visual cortical circuit of constitutive and PV-specific Fmrl KO mice, strongly suggesting a functional interaction between fragile X mental retardation protein and RA signaling pathways. Together, our results demonstrate that RA/RAR $\alpha$ signaling acts as a key component for homeostatic regulation of synaptic transmission at the inhibitory synapses of the visual cortex.
\end{abstract}

Key words: binocular enucleation; homeostatic plasticity; inhibitory synapses; parvalbumin-positive neuron; retinoic acid receptor

Significance Statement

In vitro studies established that retinoic acid (RA) and its receptor RAR $\alpha$ play key roles in homeostatic synaptic plasticity, a mechanism by which synaptic excitation/inhibition balance and network stability are maintained. However, whether synaptic RA signaling operates in vivo remains undetermined. Here, using a conditional RAR $\alpha$ KO mouse and cell type-specific Cre-driver lines, we showed that RAR $\alpha$ signaling in parvalbumin-expressing interneurons is crucial for visual deprivation-induced homeostatic synaptic plasticity at inhibitory synapses in visual cortical circuits. Importantly, this form of synaptic plasticity is absent when fragile $\mathrm{X}$ mental retardation protein is selectively deleted in parvalbumin-expressing interneurons, suggesting a functional connection between RAR $\alpha$ and fragile $\mathrm{X}$ mental retardation protein signaling pathways in vivo. Thus, dysfunction of RAdependent homeostatic plasticity may contribute to cortical circuit abnormalities in fragile $\mathrm{X}$ syndrome.

\section{Introduction}

More than two decades after its initial discovery in invertebrate and vertebrate nervous systems (Turrigiano et al., 1994, 1998;

\footnotetext{
Received May 4, 2018; revised Sept. 17, 2018; accepted 0ct. 10, 2018.

Author contributions: L.R.Z. wrote the first draft of the paper; L.C. edited the paper; L.R.Z. and L.C. designed research; L.R.Z. and E.P. performed research; T.C.S. contributed unpublished reagents/analytic tools; L.R.Z., X.C., and E.P. analyzed data.

This work was supported by National Institute of Mental Health Grants R01MH104227 and R01MH109475 to L.C., and Eunice Kennedy Shriver National Institute of Child Health and Human Development Grant R01HD084215 to L.C. and Grant R01MH092931 to T.C.S.

The authors declare no competing financial interests.
}

O'Brien et al., 1998), homeostatic plasticity is now well accepted as an essential mechanism through which neural circuits maintain their stability in response to chronic changes in neuronal firing activity and/or synaptic excitation and inhibition (Turrigiano, 2012). Numerous efforts have been made to understand the signaling pathways that are involved in the process of homeo-

Correspondence should be addressed to Dr. Lu Chen, Stanford University, 265 Campus Drive, G1034, Stanford, CA 94305-5453. E-mail: luchen1@stanford.edu.

https://doi.org/10.1523/JNEUROSCl.1133-18.2018

Copyright $\odot 2018$ the authors $\quad 0270-6474 / 18 / 3810454-13 \$ 15.00 / 0$ 
static synaptic plasticity (Yu and Goda, 2009). Many signaling molecules, such as CaMKII $\alpha / \beta$, CaMKIV, calcineurin, MeCP2, Arc/Arg3.1, BDNF, eEF2K/eEF2, homer 1a, and TNF $\alpha$, have been shown to be involved in various forms of homeostatic synaptic plasticity in the vertebrate CNS (Thiagarajan et al., 2002; Shepherd et al., 2006; Stellwagen and Malenka, 2006; Ibata et al., 2008; Hu et al., 2010; Jakawich et al., 2010; Blackman et al., 2012; Qiu et al., 2012; Kim and Ziff, 2014; Kavalali and Monteggia, 2015). Among these, retinoic acid (RA) and its receptor $\operatorname{RAR} \alpha$, acting through a nongenomic mechanism, have emerged as essential new players mediating homeostatic synaptic plasticity (Chen et al., 2014). RA, produced in an activity-dependent manner, binds to its receptor RAR $\alpha$ and relieves its translational repression onto a whole array of mRNAs, including those encoding $\alpha$-amino-3-hydroxy-5-methyl-4-isoxazolepropionic acid receptor (AMPAR) GluA1 subunits (Aoto et al., 2008; Poon and Chen, 2008). It has been established that RA regulates both synaptic excitation and inhibition (Sarti et al., 2013; Yee and Chen, 2016), and that postsynaptic calcium signaling is involved (Wang et al., 2011; Arendt et al., 2015b). Importantly, RA signaling and RAmediated homeostatic synaptic plasticity are completely absent in the fragile X syndrome (FXS) model mouse (Soden and Chen, 2010; Sarti et al., 2013) and FXS human neurons (Z. Zhang et al., 2018), indicating that compromised synaptic RA signaling may be implicated in neuropsychiatric disorders. However, it remains unclear whether RA functions in an in vivo setting and where in a specific neural circuit RA executes its function.

Homeostatic synaptic plasticity has been reported in a wide range of brain regions, including, but not limited to, sensory cortices and hippocampus (Feldman, 2009; Turrigiano, 2012; Lee and Whitt, 2015). The visual cortex is a classic model system used for synaptic plasticity studies. Visual inputs can be readily manipulated to induce changes in the circuits of visual pathways by both Hebbian and homeostatic mechanisms (Wiesel and Hubel, 1963, 1965; Gordon and Stryker, 1996; Desai et al., 2002; Frenkel and Bear, 2004; Goel and Lee, 2007; Gao et al., 2010; J. Zhang et al., 2011). For example, dark rearing in young animals prevents the developmental decline of mEPSC amplitude in cortical pyramidal neurons (PNs) (Desai et al., 2002) and delays the closure of the critical period of the visual cortex (Hensch et al., 1998). By contrast, dark rearing in adult animals increases mEPSC amplitudes in visual cortical PNs (Goel and Lee, 2007) and reopens the critical period in adults (He et al., 2007). Similarly, retinal lesion induces an increase in excitatory synaptic transmission as well as a decrease in synaptic inhibition, albeit at a different time point after lesion (Keck et al., 2013). Both excitatory and inhibitory neurons demonstrate homeostatic synaptic adjustment (Barnes et al., 2017). Interestingly, in the adult frog visual system, RA signaling is shown to be upregulated in response to optic nerve injury, a manipulation that resembles visual deprivation in rodent models (Duprey-Díaz et al., 2016).

We address two important questions in the present study. First, does RA signaling play a critical role in homeostatic synaptic plasticity in the rodent visual cortex in vivo? Second, what are the neuronal targets/synaptic loci of RA signaling? Combining genetic manipulations and binocular enucleation (BE) approach, we systematically tested the role of RA signaling in various neuronal cell types and showed that $\operatorname{RAR} \alpha$ expression in parvalbumin-positive $\left(\mathrm{PV}^{+}\right)$neurons is critical for homeostatic reduction of mIPSCs observed $3 \mathrm{~d}$ after $\mathrm{BE}$. In addition, we found that fragile X mental retardation protein (FMRP) deletion in the FXS model mouse also prevented homeostatic plasticity of synaptic inhibition in visually deprived animals, which further sup- ports the notion that FMRP is required for normal RA signaling in the context of homeostatic synaptic plasticity.

\section{Materials and Methods}

Mouse husbandry and genotyping. All animals were housed following Stanford University Administrative Panel on Laboratory Animal Care guidelines. The RAR $\alpha$ floxed mouse (C57BL/6 background) has been previously described (IGBNC) (Chapellier et al., 2002; Sarti et al., 2012). WT (C57BL/6 background) and Fmr1 ${ }^{-1 y}$ mice (002700, The Jackson Laboratory) in the FVB background were obtained from The Jackson Laboratory. The conditional Fmrl $\mathrm{KO}$ mouse was generated using homologous recombination. Two loxP sites were introduced into the Fmrl gene flanking exon 3, which is an essential upstream out-of-frame exon. Both male and female mice were used for the study.

For KO experiments, RAR $\alpha^{\mathrm{fl} / \mathrm{fl}}$ mice were crossed to CaMKII-Cre (005359, The Jackson Laboratory), GAD2-Cre (010802, The Jackson Laboratory), PV-Cre (008069, The Jackson Laboratory), SST-Cre (013044, The Jackson Laboratory), or EYFP reporter mice (007903, The Jackson Laboratory). Their littermates without Cre expression served as control. Litters were genotyped for Cre and flox by PCR using the protocol described previously (Sarti et al., 2012; Yee and Chen, 2016). Primers used for Cre are as follows: forward $5^{\prime}$-CACCCTGTTACGTATA GCCG-3'; reverse 5'-GAGTCATCCTTAGCGCCGTA-3'. Primers for genotyping flox site of RAR $\alpha$ are as follows: forward 5' -GTGTGTGTGTGTATTCGCGTGC-3'; reverse 5' -ACAA AGCAAGGCTTGTAGATGC$3^{\prime}$. Two sets of primers used for constitutive Fmrl are as follows: for WT: forward 5'-GTGGTTAGCTAAAGTGAGGATGAT-3'; reverse 5' -CAGGTTTGTTGGGATTAACAGATC-3'; for Fmr1 KO: forward 5'-CACGAGACTAGTGAGACGTG-3'; reverse 5'-CTTCTGGCACCTCCAGC TT-3'. Primers for genotyping flox site of conditional Fmrl are as follows: forward 5'-TGTCCCAAGTTTCTTTACCCCA-3'; reverse 5' TAGCTCAATCCTCAGTGCCC-3'.

Binocular enucleation. P35-P40 mice were anesthetized with ketamine (100 mg/kg) before eye removal. Ophthalmic ointment (Akorn) was used to prevent infection. Enucleated mice were used after $3 \mathrm{~d}$.

Stereotaxic injections of adeno-associated viruses (AAVs). Stereotactic injections of AAVs were performed as described previously (Hammad et al., 2015). Specifically, P0 mice were anesthetized by hypothermia. Stereotactic coordinates for $\mathrm{V} 1$ injection were $0.1-0.3 \mathrm{~mm}$ rostral to lambda and 1.7-2.2 mm lateral to midline. The depth of needle penetration was at $0.7 \mathrm{~mm}$ below the surface of the skull. Efficiency and localization of AAV expression were confirmed by histochemistry of nuclear GFP encoded by the expressed inactive and active GFP-Cre recombinase fusion proteins. Mice with AAV injection were used in the postcritical period (P35-P40).

Immunocytochemistry. To verify sites of viral injection and for c-Fos immunostaining, mice were perfused with $4 \%$ PFA in PBS and their brains removed and postfixed in 30\% sucrose and 4\% PFA in PBS for 2 additional days. Coronal sections of $\mathrm{V} 1$ at the thickness of $30 \mu \mathrm{m}$ were obtained and stored in PBS at $4^{\circ} \mathrm{C}$. For c-Fos staining, visual cortical slices were first permeabilized with $0.3 \%$ Triton X-100 for $1 \mathrm{~h}$, and then blocked in $10 \%$ FBS for $1 \mathrm{~h}$. Slices were subsequently incubated with a c-Fos antibody (ABE457, EMD Millipore) overnight at $4^{\circ} \mathrm{C}$, followed by incubation with a Cy5-conjugated donkey anti-rabbit secondary antibody (711-175-152, Jackson ImmunoResearch Laboratories) for $1 \mathrm{~h}$ at room temperature. The slices were washed and mounted on slides with Vectashield-containing DAPI (H-1500, Vector Laboratories). Images were taken from 2 or 3 slices per animal. A minimal of 3 animals were analyzed for each group. Images were acquired using an Olympus BX61WI laser-scanning confocal microscope with Olympus UPlanSAPO $20 \times$ objective and analyzed using Olympus OlyVIA software (RRID: SCR_016167). The number of c-Fos ${ }^{+}$cells was quantified in a fixed area of $630 \mu \mathrm{m} \times 180 \mu \mathrm{m}$ (layer $2 / 3$ ) within sections.

Single-cell $q R T-P C R$. Single-cell mRNAs were amplified using the protocol as previously described (Park et al., 2018). Acute slices were obtained from $\mathrm{P} 35-\mathrm{P} 40$ mice and single $\mathrm{PV}^{+}$neurons visualized with a YFP reporter were extracted from L2/3 of the primary visual cortex. Cell extract volume was minimized to $1 \mu \mathrm{l}$. mRNA obtained from the 
extracts was amplified using Superscript III One-Step RT-PCR System with Platinum Taq High Fidelity DNA polymerase (Invitrogen, catalog \#12574035). qRT-PCR was then performed using TaqMan Gene Expression Master Mix (Applied Biosystems, catalog \#4369016) with TaqMan primers from Invitrogen: RAR $\alpha$ (Mm00436262_m1), Actin $\beta$ (Mm02619580_g1), GFAP (Mm01253033_m1), and PV (Mm00443100_m1). Actin $\beta$ was used as the endogenous control. Cells expressing GFAP, a marker for astrocytes, were excluded from the sample.

Drugs and chemicals. All-trans RA (R2625), and picrotoxin (P1675) were purchased from Sigma-Aldrich. TTX (1078), D-APV (0106), and CNQX (0190) were from Tocris Bioscience.

Acute slice electrophysiology recordings. Mice between P21 and P40 were anesthetized with $\mathrm{CO}_{2}$, and brains were quickly removed and transferred into ice-cold high sucrose solution containing the following (in $\mathrm{mm}$ ): 70 $\mathrm{NaCl}, 2.5 \mathrm{KCl}, 1.25 \mathrm{NaH}_{2} \mathrm{PO}_{4}, 26 \mathrm{NaHCO}_{3}, 25$ glucose, 75 sucrose, 4 $\mathrm{MgCl}_{2}$, and $0.5 \mathrm{CaCl}_{2}$. Coronal slices of $300 \mu \mathrm{m}$ were made with a vibratome (Leica Microsystems, VT1200) in high sucrose solution. After cutting, slices were immediately moved to $32^{\circ} \mathrm{C}-34^{\circ} \mathrm{C}$ ACSF containing the following (in mM): $120 \mathrm{NaCl}, 26 \mathrm{NaHCO}_{3}, 2.5 \mathrm{KCl}, 11$ glucose, 2 $\mathrm{CaCl}_{2}, 2 \mathrm{MgSO}_{4}$, and $1 \mathrm{NaH}_{2} \mathrm{PO}_{4}$. ACSF and high sucrose solution are balanced with $5 \% \mathrm{CO}_{2} / 95 \% \mathrm{O}_{2}$. Slices were allowed to recover at $32^{\circ} \mathrm{C}-$ $34^{\circ} \mathrm{C}$ for $30 \mathrm{~min}$, followed by incubation in ACSF at room temperature. $\mathrm{RA}(2 \mu \mathrm{M})$ was added to the incubating ACSF at room temperature. To compensate for the loss of RA resulting from oxidation by bubbling with $5 \% \mathrm{CO}_{2} / 95 \% \mathrm{O}_{2}$, two additional supplements of RA $(2 \mu \mathrm{M})$ were added $45 \mathrm{~min}$ and $90 \mathrm{~min}$ after the first treatment. Electrophysiology recordings were done between 2 and $4 \mathrm{~h}$ after the first RA treatment.

For synaptic responses, voltage-clamp whole-cell recordings were obtained from $\mathrm{PNs}$ or $\mathrm{PV}^{+}$neurons at layer II/III of the monocular zone of the primary visual cortex, under visual guidance using transmitted light illumination. The recording chamber was perfused with ACSF gassed with $5 \% \mathrm{CO}_{2} / 95 \% \mathrm{O}_{2}$. Spontaneous miniature transmission was obtained in the presence of $1 \mu \mathrm{M}$ TTX in the external solution. The $100 \mu \mathrm{M}$ picrotoxin or $50 \mu \mathrm{M}$ D-APV and $10 \mu \mathrm{M}$ CNQX were added to perfusion ACSF for mEPSC or mIPSC recordings, respectively. Patch recording pipettes $(3-6 \mathrm{~m} \Omega)$ are filled with an internal solution containing the following (in mM): $140 \mathrm{CsCl}, 10$ HEPES, $2 \mathrm{MgCl}_{2}, 4 \mathrm{Na}_{2} \mathrm{ATP}, 0.4$ $\mathrm{Na}_{3} \mathrm{GTP}$, and 5 EGTA, $\mathrm{pH}$ 7.3. Stable recordings were ensured by online monitoring of Rm, Ra, and $\mathrm{Cm}$. Neurons with $>10 \%$ changes in $\mathrm{Rm}, \mathrm{Ra}$, or $\mathrm{Cm}$ were excluded from further analysis.

For membrane excitability experiments, whole-cell recordings in current-clamp mode were obtained from $\mathrm{PV}^{+}$neurons at layer II/III of the monocular zone of the primary visual cortex. $\mathrm{PV}^{+}$neurons were identified with Cre-dependent YFP reporter expression in PV-Cre mice. Internal solution used in this experiment contains (in $\mathrm{mM}$ ): 130 K-gluconate, $10 \mathrm{KCl}, 10 \mathrm{HEPES}, 5 \mathrm{MgATP}, 0.3 \mathrm{Na}_{3} \mathrm{GTP}$, and 0.2 EGTA, $\mathrm{pH}$ 7.3. Cell excitability was assessed with injections of incremental current steps (50-350 pA at a step interval of $50 \mathrm{pA}$ for $1 \mathrm{~s})$. The number of action potentials elicited by injected currents was counted.

Pclamp version 10.1 (Molecular Devices, RRID:SCR_011323) was used for data visualization and collection. Synaptic responses were analyzed with Clampex 10.1 (Molecular Devices), MiniAnalysis software (Synaptosoft, RRID:SCR_002184), and Excel (Microsoft, RRID: SCR_016137). Cumulative plots of mEPSC and mIPSC interevent intervals and amplitudes were generated by pooling 50 randomly selected events from each cell.

Statistical analysis. All graphs represent mean \pm SEM values. For each experimental group, $N$ and $n$ indicate the number of independent experiments and total number of neurons, respectively, and are indicated in the figures. Normality test, Student's $t$ test, KomolgrowSmirnov test, Mann-Whitney test, or two-way ANOVA followed by post hoc Tukey's test was used for statistical analysis using OriginPro (RRID:SCR_015636).

Based on actual effect sizes and sample sizes, the range of power achieved in our experiments is between 0.85 and $0.99(\alpha=0.05)$.

\section{Results}

\section{Acute RA treatment modulates mIPSC frequency and amplitude in $\mathrm{L} 2 / 3$ PNs}

We have previously shown that RA modulates both excitatory and inhibitory synaptic strength onto hippocampal PNs (Aoto et al., 2008; Soden and Chen, 2010; Sarti et al., 2013; Arendt et al., 2015a) and inhibitory synapses onto somatosensory cortical L2/3 PNs (Yee and Chen, 2016). Thus, we first wanted to determine whether RA is able to regulate synaptic strength in visual cortical circuits as well. Given the established role of RA in homeostatic synaptic plasticity, we focused on L2/3 PNs in the monocular zone of the primary visual cortex $(\mathrm{V} 1 \mathrm{~m})$ where robust visual experience-induced homeostatic synaptic plasticity has been previously reported (Goel and Lee, 2007; Keck et al., 2013). Incubating acute cortical slices from postcritical period (P35-P40) mice in $2 \mu \mathrm{M}$ RA for $2-4 \mathrm{~h}$ did not significantly alter spontaneous mEPSCs (frequency: control, $1.14 \pm 0.15 \mathrm{~Hz}$; RA, $1.30 \pm 0.14 \mathrm{~Hz}$; amplitude: control, $9.91 \pm 0.26 \mathrm{pA}$; RA, $9.64 \pm 0.25 \mathrm{pA}$ ) (Fig. $1 A-C$ ) but significantly reduced both mIPSC frequency (control, $7.55 \pm 0.28 \mathrm{~Hz}$; RA, $4.60 \pm 0.26 \mathrm{~Hz}$ ) and amplitude (control, $36.63 \pm 1.09 \mathrm{pA} ; \mathrm{RA}, 30.51 \pm 1.40 \mathrm{pA})($ Fig. $1 D-F)$.

Cortical neurons often exhibit distinct synaptic properties during and after the critical period. We thus examined RA's effect on synaptic transmission during the visual cortical critical period. In slices taken from younger animals within the critical period (P21-P30), acute RA treatment did not change mEPSCs (Fig. $1 G$; frequency: control, $1.65 \pm 0.12 \mathrm{~Hz}$; RA, $1.54 \pm 0.12 \mathrm{~Hz}$; amplitude: control, $8.73 \pm 0.14 \mathrm{pA}$; RA, $8.63 \pm 0.16 \mathrm{pA}$ ) but induced a small yet significant increase in mIPSC amplitudes (Fig. $1 \mathrm{H}$; frequency: control, $4.09 \pm 0.20 \mathrm{~Hz}$; RA, $4.22 \pm 0.22 \mathrm{~Hz}$; amplitude: control, $23.77 \pm 0.63 \mathrm{pA}$; RA, $25.84 \pm 0.62 \mathrm{pA})$. Together, our data suggest that RA signaling does operate in L2/3 visual cortical circuits and that it primarily affects inhibitory synaptic transmission onto L2/3 PNs in the postcritical period (P35-P40).

RAR $\alpha$ mediates synaptic RA signaling at both excitatory and inhibitory synapses in hippocampal neurons (Aoto et al., 2008; Poon and Chen, 2008; Sarti et al., 2012). To investigate whether RAR $\alpha$ also mediates RA's effect in cortical neurons in the postcritical period, we injected AAV-expressing Cre recombinase or a truncated and thus inactive Cre (mCre control) under the synapsin promoter in the V1m of P0 RAR $\alpha$ conditional KO mice (Fig. 1I) (Kaeser et al., 2011). mIPSC frequencies in the WT (mCreinfected) neurons responded to RA treatment as expected (Fig. $1 J$ ) (Control, $5.62 \pm 0.26 \mathrm{~Hz}$; RA, $4.00 \pm 0.25 \mathrm{~Hz}$ ). However, in the Cre-infected neurons, RAR $\alpha$ deletion completely blocked RA-induced reduction in mIPSC frequency (Fig. $1 J$ ) (Control, $6.04 \pm 0.30 \mathrm{~Hz}$; RA, $5.77 \pm 0.32 \mathrm{~Hz}$ ). RAR $\alpha$ deletion also significantly reduced mIPSC amplitude in neurons treated with vehicle (Fig. $1 K)$ (mCre, $28.87 \pm 1.42$ pA; Cre, $23.90 \pm 0.64$ pA). These results demonstrate that RAR $\alpha$ is a key mediator for RA's effect on spontaneous inhibitory synaptic transmission.

\section{RAR $\alpha$ expression in $\mathrm{PV}^{+}$interneurons mediates RA's impact on mIPSCs of L2/3 PNs}

Cortical PNs receive inhibitory input from multiple sources, including PV- and somatostatin (SST)-expressing GABAergic interneurons (Pfeffer et al., 2013). RA signaling in either the presynaptic neurons (i.e., inhibitory interneurons) or the postsynaptic neurons (i.e., PNs) could contribute to mIPSC alterations by RA. To determine the loci of RA signaling that mediate the reduction of mIPSC frequency in L2/3 PNs, we crossed the CaMKII $\alpha$-Cre and GAD2-Cre mouse driver lines with the RAR $\alpha$ conditional KO mouse. $\mathrm{RAR} \alpha$ deletion in forebrain excitatory 
A

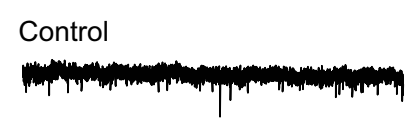

RA

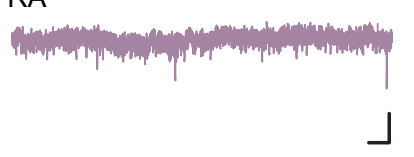

D

Control

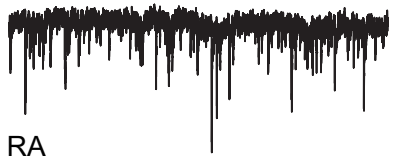

RA

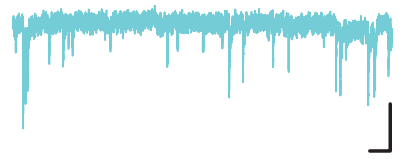

G

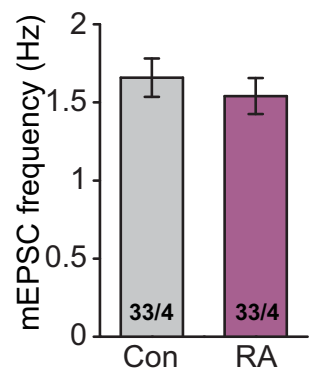

B

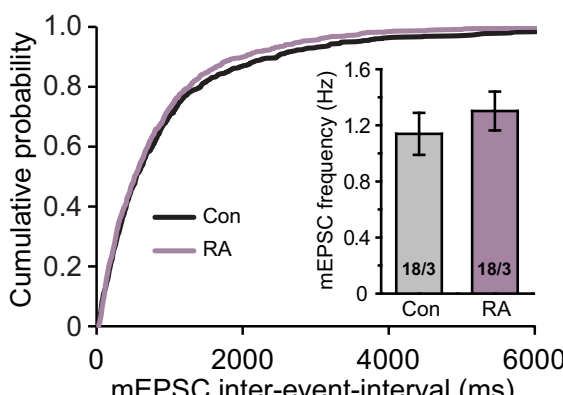

E

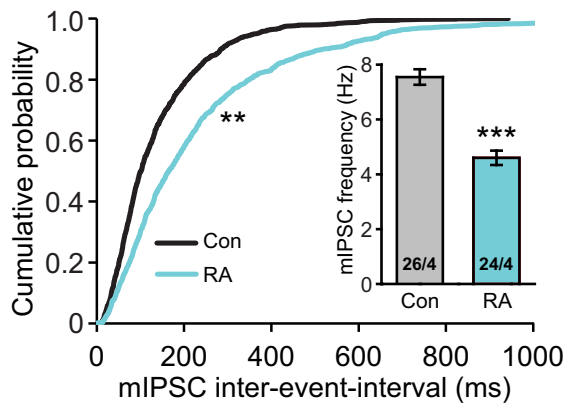

C

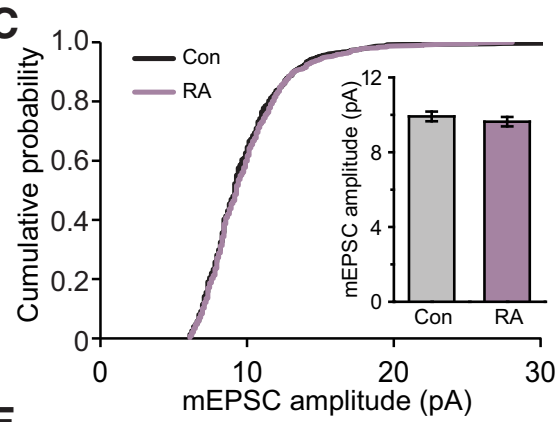

F

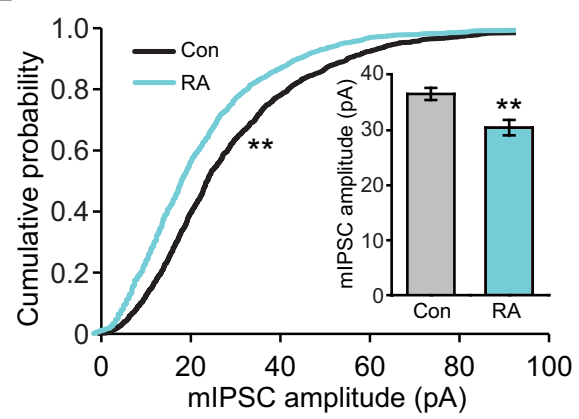

H
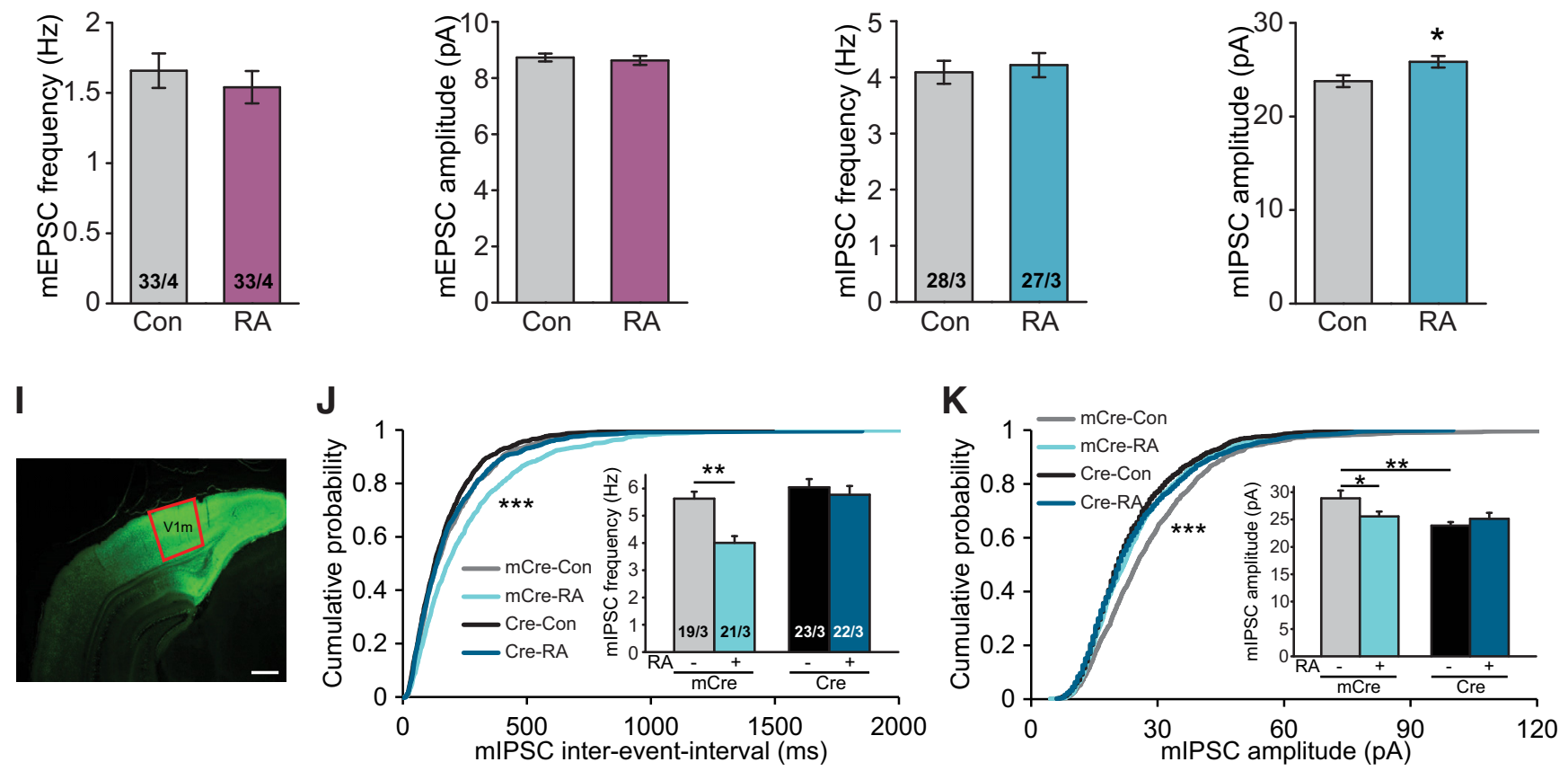

Figure 1. RAR $\alpha$ mediates regulation of inhibitory synaptic transmission by RA.A, Example traces of mEPSCs recorded from postcritical period (P35-P40) vehicle-treated and RA-treated V1m L2/3 PNs. Calibration: $20 \mathrm{pA}, 0.5 \mathrm{~s}$. B, Cumulative plot of mEPSC interevent interval and quantification of mEPSC frequencies in PNs of control and RA groups. C, Cumulative plot and quantification of $m$ EPSC amplitudes in PNs treated with vehicle or RA. D, Example traces of mIPSCs from control and RA-treated V1m L2/3 PNs. Calibration: 50 pA, 0.5 s. E, F, Quantification of mIPSC frequencies and amplitudes. ${ }^{* *} p<0.01$ (Student's $t$ test and Kolmogorov-Smirnov test). ${ }^{* * *} p<0.001$ (Student's $t$ test and Kolmogorov-Smirnov test). G, Quantification of mEPSC frequencies and amplitudes recorded from critical period (P20 -P30) V1m L2/3 PNs neurons treated with vehicle or RA. $\boldsymbol{H}$, Quantification of mIPSC frequencies and amplitudes in critical period PNs from vehicle or RA groups. ${ }^{*} p<0.05$ (Student's $t$ test). I, An example image of an acute brain slice taken from a mouse injected with Cre-GFP-expressing AAVs in V1. Scale bar, $500 \mu \mathrm{m}$. $J, K$, Quantification of mIPSC frequencies and amplitudes recorded from mice in the postcritical period injected by AAV-Syn-Cre or AAV-Syn-mCre treated with either vehicle or RA. ${ }^{*} p<0.05$ (two-way ANOVA and Kolmogorov-Smirnov test). ${ }^{* *} p<0.01$ (two-way ANOVA and Kolmogorov-Smirnov test). ${ }^{* *} p<0.001$ (two-way ANOVA and Kolmogorov-Smirnov test).

neurons (CaMKII $\alpha$-Cre; RAR $\left.\alpha^{\mathrm{fl} / \mathrm{fl}}\right)$ or inhibitory neurons did not affect mIPSC baseline (Fig. 2A). In CaMKII $\alpha$-RAR $\alpha$ KOs, RA treatment still significantly reduced mIPSC frequencies and amplitudes in PNs (Fig. 2B, C; frequency: Control, $7.24 \pm 0.42 \mathrm{~Hz}$; RA, $4.27 \pm 0.34 \mathrm{~Hz}$; amplitude: Control, $30.02 \pm 1.26 \mathrm{pA}$; RA, $27.11 \pm 0.73 \mathrm{pA})$. By contrast, deletion of RAR $\alpha$ from most inhibitory neurons (GAD2-Cre; RAR ${ }^{\mathrm{fl} / \mathrm{fl}}$ ) completely eliminated RA's effect on mIPSCs (Fig. $2 B, C$; frequency: Control,
$6.46 \pm 0.39 \mathrm{~Hz} ; \mathrm{RA}, 6.23 \pm 0.33 \mathrm{~Hz}$; amplitude: Control, $27.07 \pm$ $0.78 \mathrm{pA}$; RA, $27.09 \pm 0.83 \mathrm{~Hz}$ ).

To further dissect interneuron subtypes through which RA signaling acts upon, we selectively deleted RAR $\alpha$ from PV- and SST-expressing neurons using their respective Cre driver lines. Neither line had any significant change in basal synaptic transmission (Fig. 2A). RAR $\alpha$ deletion in $\mathrm{PV}^{+}$neurons blocked the effects of RA on both mIPSC frequency and amplitude (Fig. 
A
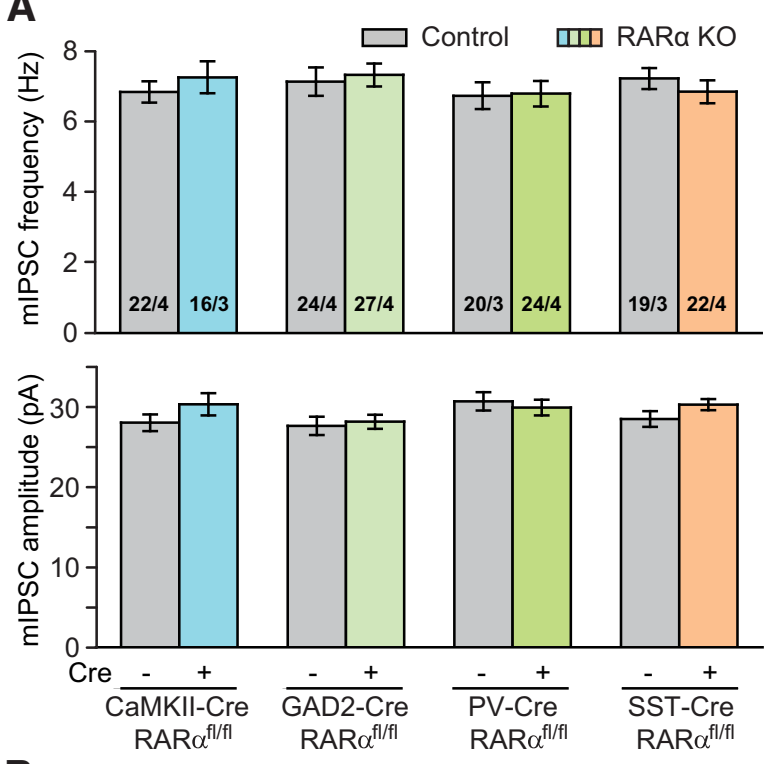

B

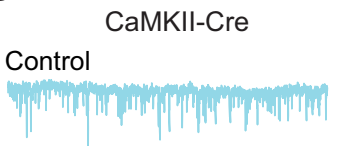

RA
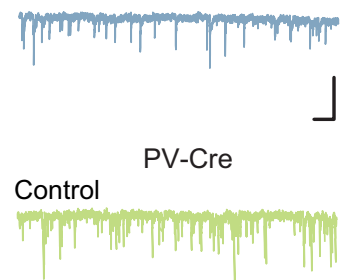

RA

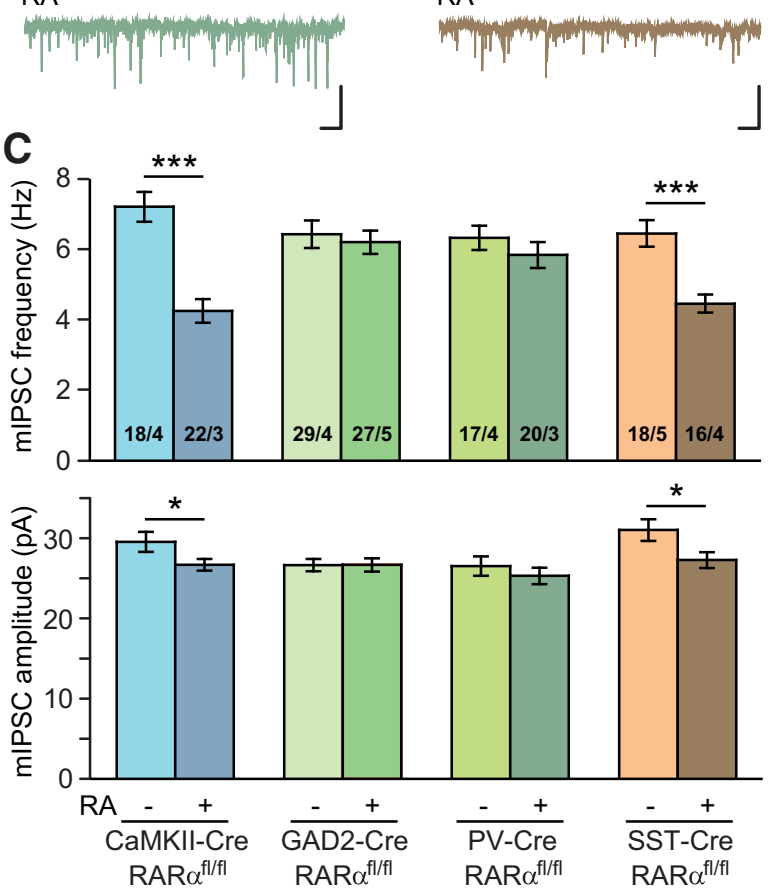

Figure 2. RAR $\alpha$ expression in $\mathrm{PV}^{+}$neurons mediates RA's effect on inhibitory synaptic transmission in L2/3 PNs. $A$, Quantification of basal mIPSCs in cell type-specific RAR $\alpha$ cKO mice (RAR $\alpha^{\mathrm{fl} / \mathrm{fl}}$ crossed with CaMKIII $\alpha$-Cre, GAD2-Cre, PV-Cre, and SST-Cre). B, Representative traces of mIPSCs recorded from vehicle- or RA-treated PNs from CaMKIII $\alpha$-Cre; RAR $\alpha^{\mathrm{fl} / \mathrm{fl}}$,
2 B, C; frequency: Control, $6.35 \pm 0.35 \mathrm{~Hz}$; RA, $5.87 \pm 0.37 \mathrm{~Hz}$; amplitude: Control, $26.96 \pm 1.22 \mathrm{pA}$; RA, $25.70 \pm 1.03 \mathrm{pA})$, whereas $\mathrm{RAR} \alpha$ deletion in $\mathrm{SST}^{+}$neurons did not (Fig. $2 \mathrm{~B}, \mathrm{C}$; frequency: Control, $6.48 \pm 0.38 \mathrm{~Hz}$; RA, $4.48 \pm 0.26 \mathrm{~Hz}$; amplitude: Control, $31.52 \pm 1.37 \mathrm{pA}$; RA, $27.71 \pm 1.00 \mathrm{pA})$. Thus, RAR $\alpha$ expression in $\mathrm{PV}^{+}$neurons is essential for RA's effect on mIPSCs onto PNs.

\section{Visual deprivation causes a reduction in spontaneous inhibitory synaptic transmission}

Visual deprivation induces homeostatic compensation at cortical synapses during both critical and postcritical periods (Desai et al., 2002; Maffei et al., 2004; Goel and Lee, 2007; Keck et al., 2013). We adopted $\mathrm{BE}$ as a model system to induce homeostatic synaptic plasticity (Fig. $3 A$ ). To validate the effect of BE on cortical activity, we performed immunostaining of c-Fos, a marker for neuronal activity, in visual cortex of brain slices obtained from mice experienced with either normal rearing (NR) or $3 \mathrm{~d}$ of BE. Compared with mice with NR, mice after $3 \mathrm{~d}$ of BE showed greatly reduced c-Fos expression in all visual cortical layers (Fig. $3 B$ ). In particular, in layer $2 / 3$ of $\mathrm{V} 1 \mathrm{~m}$, the number of $\mathrm{c}-\mathrm{Fos}{ }^{+}$cells was reduced by $>90 \%$ in the $\mathrm{BE}$ group compared with the NR group (Fig. 3C; NR, $105.17 \pm 12.82$; BE, $6.86 \pm 1.24$ ), suggesting that $\mathrm{BE}$-induced visual deprivation drastically reduced neuronal activity in the visual cortex. Next, V1m layer 2/3 PNs from P35-P40 mice were recorded $3 \mathrm{~d}$ after BE, and both mEPSC and mIPSCs were measured. Similar to previous reports (Keck et al., 2013), changes in mEPSC frequency (Fig. $3 E$; NR, $2.85 \pm 0.25 \mathrm{~Hz} ; \mathrm{BE}$, $2.49 \pm 0.38 \mathrm{~Hz}$ ) and mEPSC amplitude (Fig. 3F; NR, $10.56 \pm$ $0.32 \mathrm{pA} ; \mathrm{BE}, 11.32 \pm 0.40 \mathrm{pA})$ at this late time point were no longer obvious, likely because homeostatic changes at excitatory synapses occur earlier (He et al., 2012), although the Kolmogorov-Smirnov test showed significant differences in mEPSC amplitude and frequency distribution between NR and BE groups. At this age, excitatory synaptic strength may have already reequilibrated back to prelesion levels $3 \mathrm{~d}$ after BE due to changes at other loci of the network. However, consistent with previous reports (Keck et al., 2013), both mIPSC frequency and amplitude were significantly decreased after $3 \mathrm{~d}$ of visual deprivation (Fig. $3 G-I$; frequency: NR, $7.25 \pm 0.40 \mathrm{~Hz}$; BE, $4.84 \pm 0.25 \mathrm{~Hz}$; amplitude: NR, $29.53 \pm 1.00 \mathrm{pA}$; BE, $25.03 \pm 1.01 \mathrm{pA}$ ).

\section{RAR $\alpha$ deletion in $\mathrm{PV}^{+}$neurons blocks visual deprivation-induced synaptic inhibition}

Given RA's established role in mediating homeostatic synaptic plasticity and that RAR $\alpha$ expression in $\mathrm{PV}^{+}$interneurons is essential for RA's effect on mIPSC (Fig. 2), we sought to test whether $\mathrm{RAR} \alpha$ expression in $\mathrm{PV}^{+}$interneurons is also required for homeostatic synaptic changes of mIPSC after visual deprivation. Indeed, $\mathrm{RAR} \alpha$ deletion in $\mathrm{PV}^{+}$interneurons completely prevented the changes in mIPSCs induced by BE (Fig. $4 A, B$; WT frequency: NR, $6.78 \pm 0.36 \mathrm{~Hz}$; BE, $5.01 \pm 0.21 \mathrm{~Hz}$; WT amplitude: NR, $30.17 \pm 1.06$ pA; BE, $25.42 \pm 0.92$ pA; PV-RAR $\alpha$ KO frequency: NR, $7.35 \pm 0.29 \mathrm{~Hz}$; BE, $6.63 \pm 0.12 \mathrm{~Hz}$; PV-RAR $\alpha$ KO amplitude: NR, $30.63 \pm 0.92$ pA; BE, $29.84 \pm 1.12$ pA). By contrast, deletion of $\operatorname{RAR} \alpha$ in $\mathrm{SST}^{+}$interneurons had no effect on homeostatic plasticity of mIPSCs induced by BE (Fig. 4C,D;

GAD2-Cre; RAR $\alpha^{\mathrm{f} / \mathrm{fl}}, \mathrm{PV}-\mathrm{Cre} ; \mathrm{RAR} \alpha^{\mathrm{fl} / \mathrm{fl}}$, SST-Cre; RAR $\alpha^{\mathrm{fl} / \mathrm{fl}}$ mice. Calibration: 50 pA, 0.5 s. C, Quantification of $\mathrm{mIPSC}$ frequencies and amplitudes in neurons treated with vehicle or RA. ${ }^{*} p<0.05$ (Student's $t$ test). ${ }^{* * *} p<0.001$ (Student's $t$ test). 
A Normal Rearing Binocular Enucleation
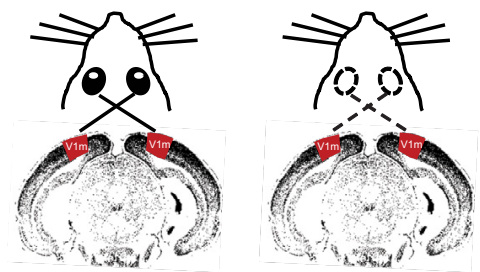

D

NR

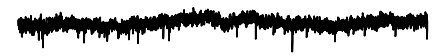

BE

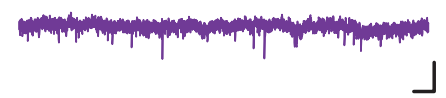

G

NR

"Wy

BE

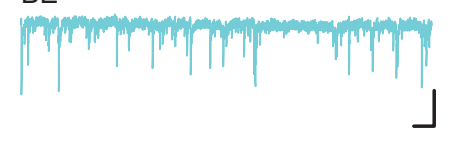

B

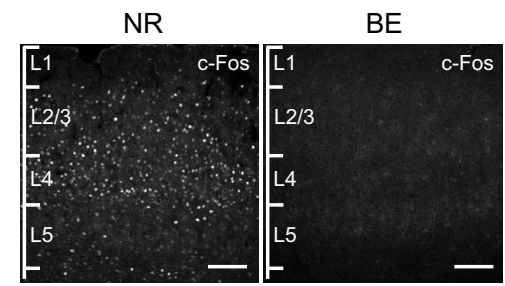

E

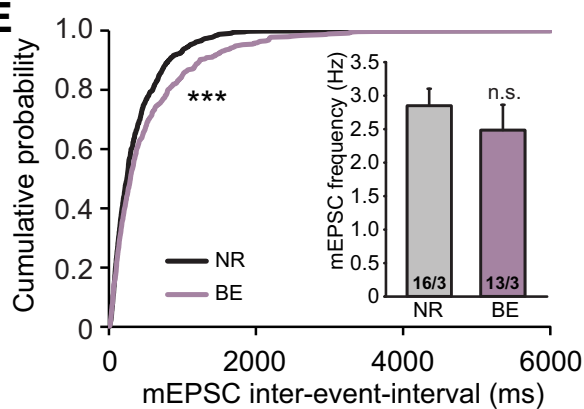

H

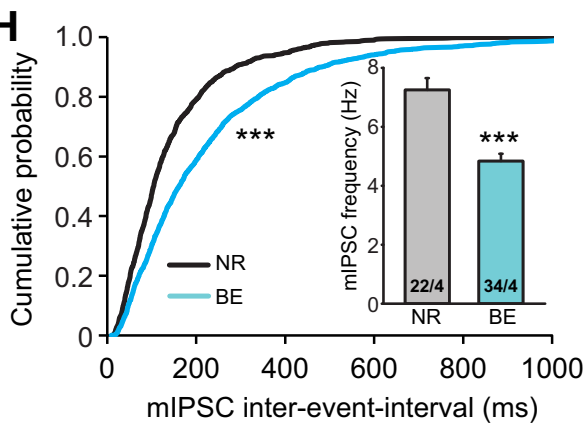

C
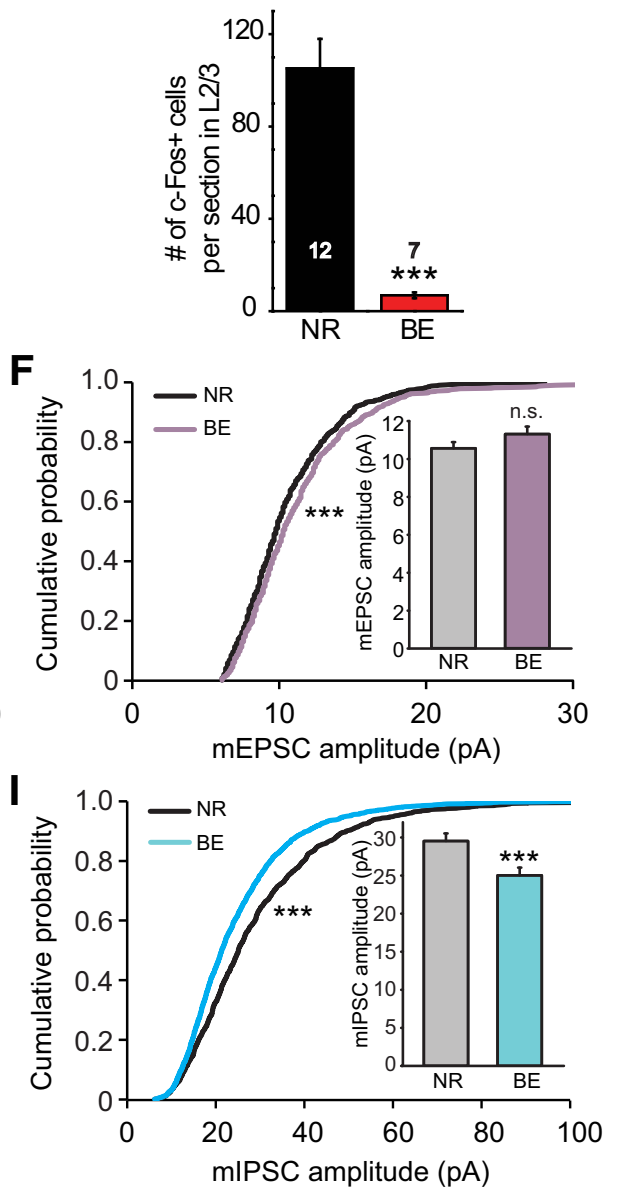

Figure 3. Visual deprivation induces homeostatic downregulation of inhibitory synaptic transmission in postcritical period visual cortices. $A$, Diagram of mice with NR and BE conditions. Recordings were made from L2/3 PNs in the P35-P40 V1m $3 \mathrm{~d}$ after BE or mock treatment. B, Examples of c-Fos staining from sections of V1m with NR or $3 \mathrm{~d}$ BE experience. Cortical layers (L1-L5) are marked. Scale bar, $100 \mu \mathrm{m}$. C, Quantification of total number of c-Fos ${ }^{+}$cells per imaged section $(630 \mu \mathrm{m} \times 180 \mu \mathrm{m})$ in L2/3. ${ }^{* * *} p<0.001$ (Mann-Whitney test). D, Trace examples of mEPSCs recorded in L2/3 PNs from V1m of mice with NR or BE. Calibration: 20 pA, 0.5 s. $E$, Cumulative plot of mEPSC interevent interval and quantification of mEPSC frequencies. ${ }^{* * *} p<0.001$ (Kolmogorov-Smirnov test). $\boldsymbol{F}$, Cumulative plot and quantification of average mEPSC amplitudes under NR and BE conditions. $\boldsymbol{G}$, Representative traces of mIPSCS recorded in PNs from NR and BE groups. Calibration: 50 pA, 0.5 s. H, I, Cumulative plots and quantifications of mIPSC frequency and amplitude. ${ }^{* * *} p<0.001$ (Student's $t$ test and Kolmogorov-Smirnov test).

\section{A}

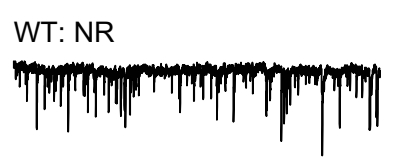

WT: BE

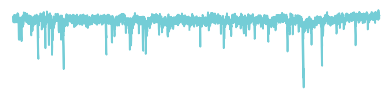

PV-Cre: NR

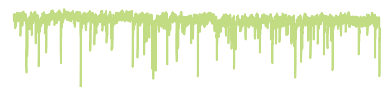

PV-Cre: BE

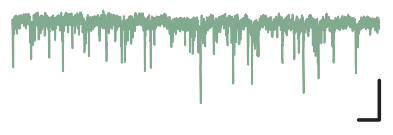

B

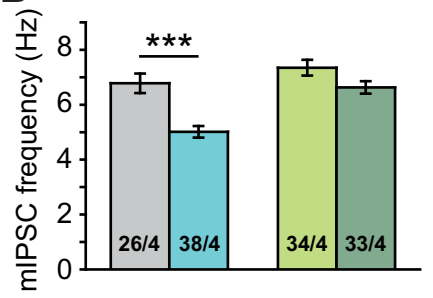

C

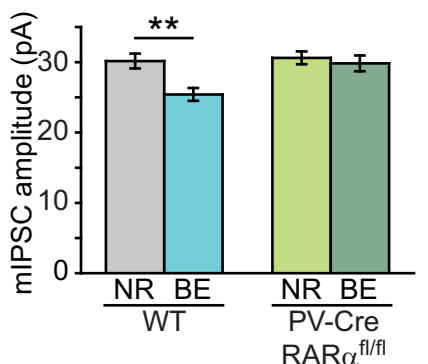

WT: NR

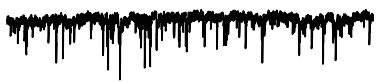

WT: BE
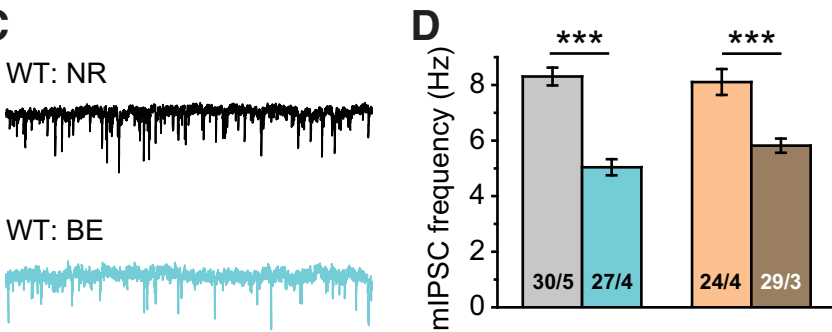

SST-Cre: NR

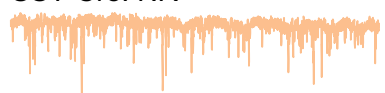

SST-Cre: BE
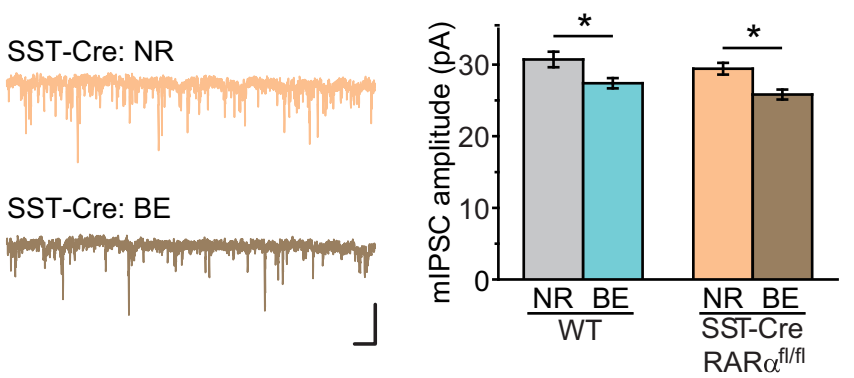

Figure 4. RAR $\alpha$ deletion in $\mathrm{PV}^{+}$neurons prevents visual deprivation-induced downregulation of inhibitory synaptic transmission in L2/3 PNs. $\boldsymbol{A}$, Representative traces recorded from layer $2 / 3$ PNs in PV-Cre; RAR $\alpha$ fl/fl and their littermate control mice with either NR or BE. Calibration: 50 pA, 0.5 s. $B$, Average mIPSC frequencies and amplitudes in mice with RAR $\alpha$ K0 in PV ${ }^{+}$neurons. ${ }^{* *} p<$ 0.01 (two-way ANOVA). ${ }^{* * *} p<0.001$ (two-way ANOVA). C, Representative traces recorded from SST-Cre; RAR $\alpha^{\text {fl/fl }}$ and their littermate control mice. Calibration: 50 pA, 0.5 s. D, Average mIPSC frequencies and amplitudes in mice with RAR $\alpha$ deletion in SST ${ }^{+}$neurons. ${ }^{*} p<0.05$ (two-way ANOVA). ${ }^{* *} p<0.001$ (two-way ANOVA). 
A
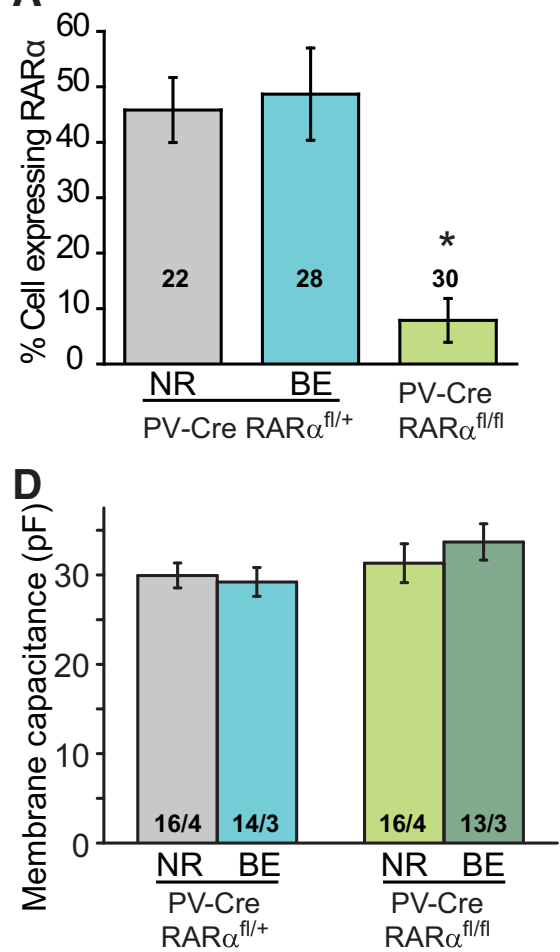

G

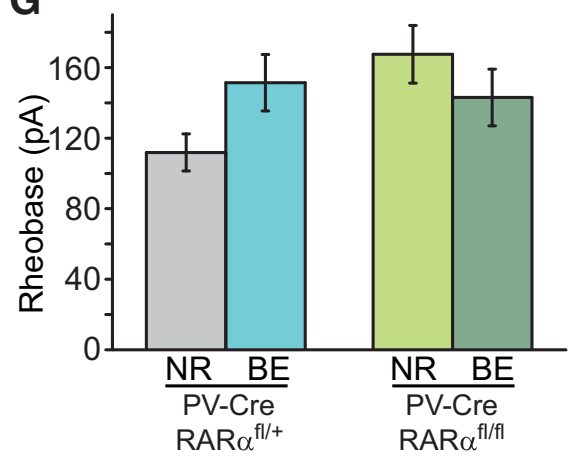

B
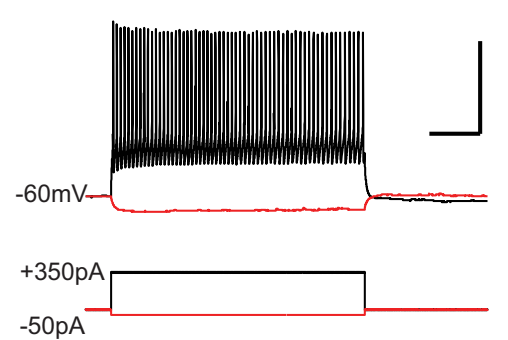

E

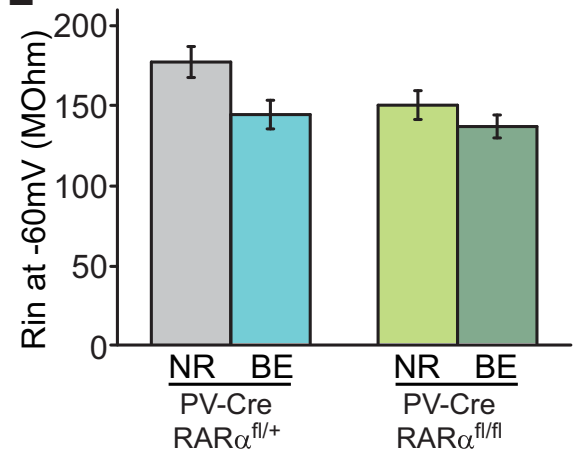

H

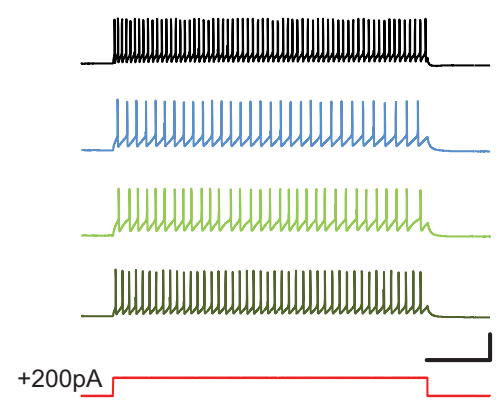

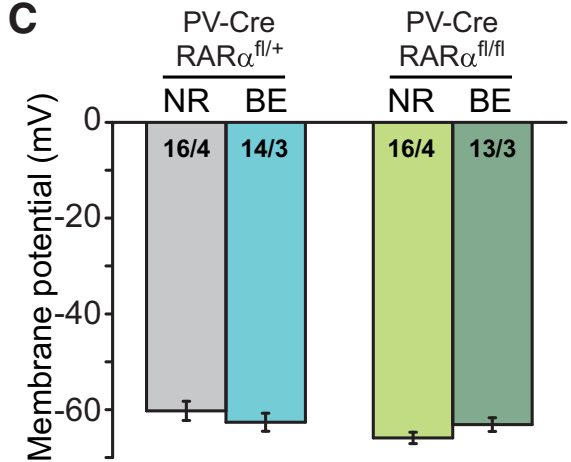

F

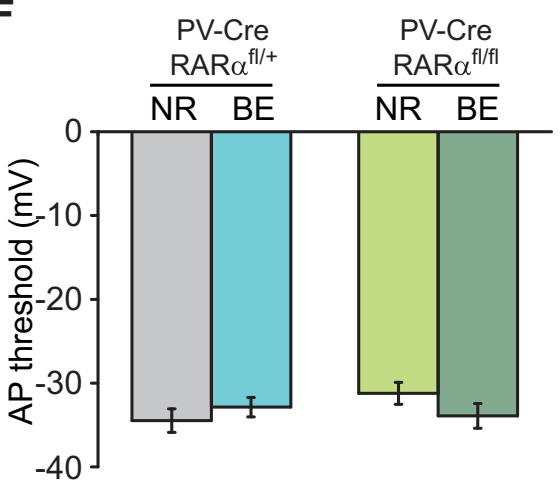

I

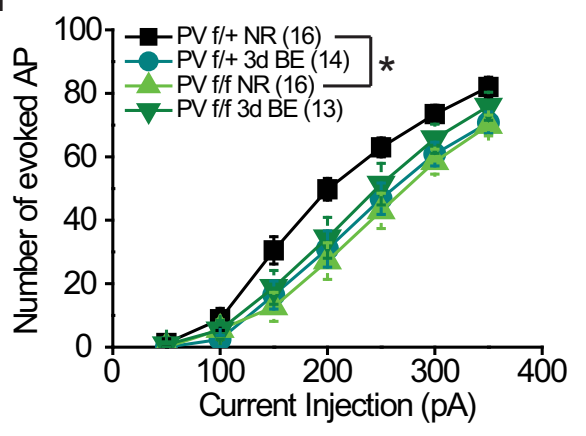

Figure 5. Visual deprivation does not affect passive and active membrane properties of $\mathrm{PV}^{+}{ }^{+}$neurons. $A$, Quantification of percentage of $L 2 / 3 \mathrm{PV}^{+}$neurons expressing RAR $\alpha \mathrm{mRNAs}$ measured with single-cell qRT-PCR in P35 PV-RARR ${ }^{\mathrm{fl} /+}$ and PV-RAR $\alpha^{\mathrm{fl} / \mathrm{fl}}$ mice. $n=$ the number of cells pooled from 3 or 4 mice per genotype. ${ }^{*} p<0.05$ (Mann-Whitney test). $\boldsymbol{B}$, Example traces recorded from PV ${ }^{+}$neurons with $350 \mathrm{pA}$ and $-50 \mathrm{pA}$ current injections. Calibration: $50 \mathrm{mV}, 0.2 \mathrm{~s}$. C-E, Quantification of passive membrane properties of PV ${ }^{+}$neurons in PV-RAR $\alpha$ KO mice (PV-Cre; $\left.\operatorname{RAR} \alpha^{\mathrm{fl} / \mathrm{fl}}\right)$ or their littermate controls (PV-Cre; RAR $\alpha^{\mathrm{fl} /+}$ ) under NR or BE conditions. Resting membrane potentials $(\boldsymbol{C})$, membrane capacitance $(\boldsymbol{D})$, and input resistance $(\boldsymbol{E})$ were analyzed. $\boldsymbol{F}, \boldsymbol{G}$, Quantification of active membrane properties (action potential threshold, $\boldsymbol{F}$; and rheobase, $\mathbf{G}$ ) of PV ${ }^{+}$neurons in PV-RAR $\alpha$ KO mice (PV-Cre; RAR $\alpha^{\mathrm{fl} / \mathrm{fl})}$ or their littermate controls (PV-Cre; $\mathrm{RAR}^{\mathrm{fl} /++}$ ) under NR or BE conditions. $\boldsymbol{H}$, Representative traces of firing activity in response to a $200 \mathrm{pA}$ step current injection recorded from PV ${ }^{+}$neurons in V1m L2/3. Calibration: $50 \mathrm{mV}, 0.2 \mathrm{~s} . \boldsymbol{I}$, Input- output relations between total number of action potentials and step current injections between 50 and $350 \mathrm{pA} .{ }^{*} p<0.05$ (two-way repeated-measures ANOVA).

WT frequency: NR, $8.31 \pm 0.32 \mathrm{~Hz}$; BE, $5.04 \pm 0.29 \mathrm{~Hz}$; WT amplitude, NR, $30.72 \pm 1.08 \mathrm{pA}$; BE, $27.40 \pm 0.72 \mathrm{pA}$; SSTRAR $\alpha$ KO frequency: NR, $8.11 \pm 0.47 \mathrm{~Hz}$; BE, $5.82 \pm 0.26 \mathrm{~Hz}$; SST-RAR $\alpha$ KO amplitude: NR, $29.43 \pm 0.82$ pA; BE, $25.82 \pm 0.70$ pA). Thus, RAR $\alpha$-dependent RA signaling in $\mathrm{PV}^{+}$interneurons is critically involved in homeostatic synaptic plasticity in $\mathrm{V} 1 \mathrm{~m}$.

\section{Visual deprivation causes similar synaptic inhibition in $\mathrm{PV}^{+}$neurons}

Visual deprivation not only induces homeostatic changes in excitatory neurons of cortical circuit, but also in local inhibitory neurons (Maffei et al., 2006). We thus asked whether our visual deprivation paradigm ( $3 \mathrm{~d} \mathrm{BE}$ ) also induces changes in inhibitory interneurons. PV-Cre and floxed $\operatorname{RAR} \alpha$ double-mutant mice were crossed with a Cre-dependent YFP-reporter line for visual- ization of $\mathrm{PV}^{+}$neurons (Madisen et al., 2010). We first examined whether RAR $\alpha$ expression in $\mathrm{V} 1 \mathrm{~m} \mathrm{PV}{ }^{+}$neurons was altered by BE with single-cell qRT-PCR. As a proof of principle, percentage of RAR $\alpha$-expressing $\mathrm{PV}^{+}$neurons was largely reduced in $\mathrm{P} 35$ PV-RAR $\alpha$ cKO mice (Fig. $5 A$; RAR $\alpha^{\mathrm{fl} /+}-\mathrm{NR}, 45.83 \pm 5.86 \%$; $\left.\mathrm{RAR} \alpha^{\mathrm{fl} / \mathrm{fl}}-\mathrm{NR}, 7.87 \pm 3.96 \%\right)$. However, $3 \mathrm{~d}$ BE did not change the number of RAR $\alpha$-expressing neurons in $\mathrm{V} 1 \mathrm{~m} \mathrm{~L} 2 / 3 \mathrm{PV}^{+}$neurons (Fig. 5A; PV-RAR $\alpha^{\mathrm{fl} /+}$-BE, $48.69 \pm 8.32 \%$ ). Therefore, $3 \mathrm{~d}$ of visual deprivation does not affect $\operatorname{RAR} \alpha$ expression levels in $\mathrm{V} 1 \mathrm{~m} \mathrm{~L} 2 / 3 \mathrm{PV}^{+}$neurons. We next recorded from visually identified $\mathrm{PV}^{+}$interneurons in $\mathrm{L} 2 / 3$ of $\mathrm{V} 1 \mathrm{~m}$, which exhibited typical fast-spiking firing patterns in response to current injections (Fig. $5 B)$. Deletion of $\operatorname{RAR} \alpha$ from $\mathrm{PV}^{+}$neurons did not affect basic passive and active membrane properties, such as resting membrane potential (Fig. 5C), membrane capacitance (Fig. 5D), input 
A

PV-Cre RAR $\alpha^{\mathrm{fl} /+}:$ NR

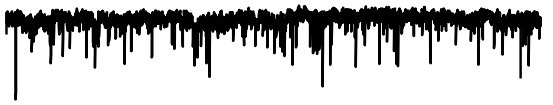

PV-Cre RAR $\alpha^{\mathrm{fl} /+}: \mathrm{BE}$

|r"w" "N"

PV-Cre RAR $\alpha^{\text {fl/fl }}:$ NR

"nn

PV-Cre RAR $\alpha^{f / f l}: B E$

MiN" pip

C

PV-Cre RAR $\alpha^{\mathrm{fl} /+}:$ NR

"

PV-Cre RAR $\alpha^{f l /+}: B E$

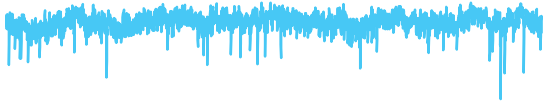

PV-Cre RAR $\alpha^{\text {fl/fl }}:$ NR

ming (p)

PV-Cre RAR ${ }^{\text {fl/fl }}:$ BE

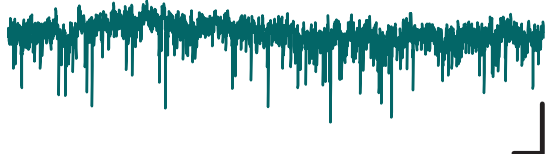

B
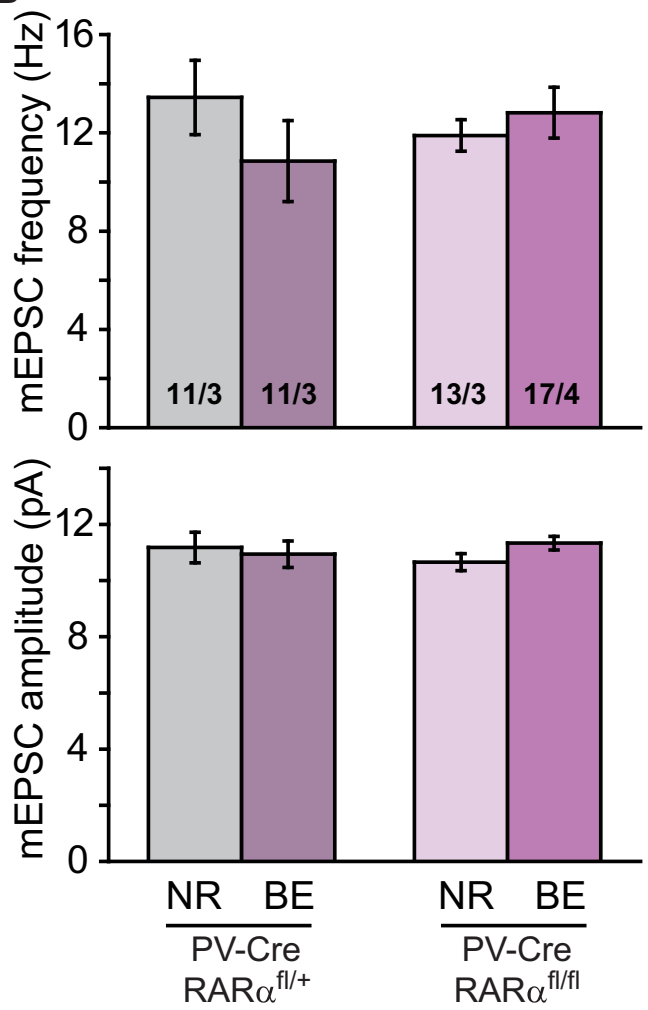

D
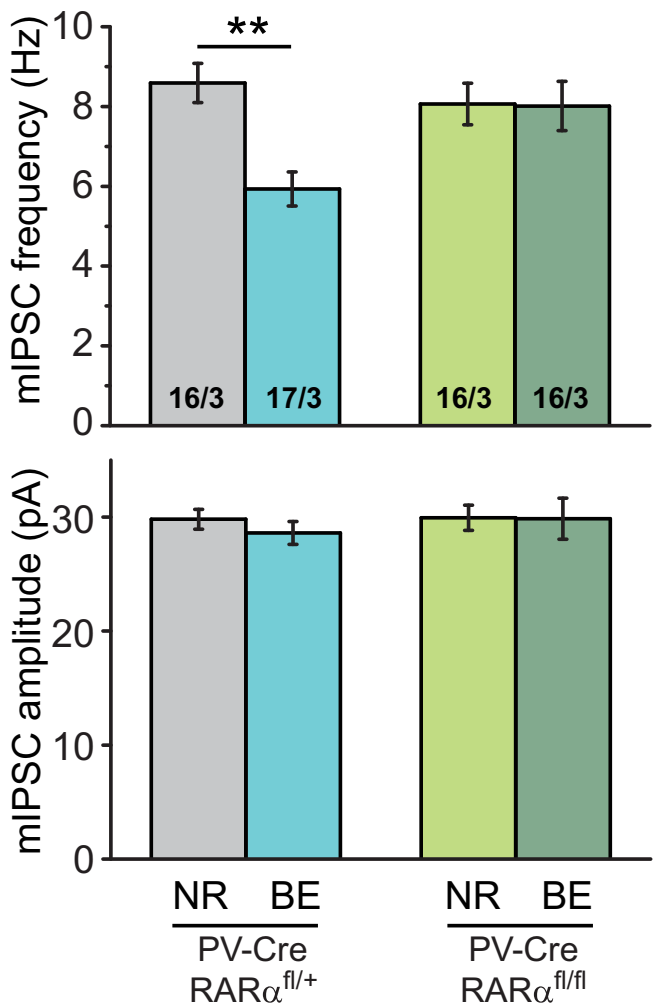

Figure 6. Visual deprivation reduces mIPSC frequencies in an RAR $\alpha$-dependent manner in PV ${ }^{+}$neurons. $A$, Representative traces of $m E P S C s$ recorded from L2/3 PV ${ }^{+}$neurons in PV-Cre; RAR $\alpha^{\mathrm{fl} /+}$ and PV-Cre; RAR $\alpha^{\mathrm{f} / \mathrm{fl}}$ mice with either NR or BE. Calibration: $20 \mathrm{pA}, 0.5 \mathrm{~s}$. B, Quantification of mEPSC frequencies and amplitudes recorded from PV ${ }^{+}$neurons in mice with PV-Cre; $\mathrm{RAR} \alpha^{\mathrm{fl} / \mathrm{fl}}$ or its littermate control PV-Cre; RAR $\alpha^{\mathrm{fl} /+}$. C, Representative traces of mIPSCs recorded from L2/3 PV ${ }^{+}$neurons. Calibration: $50 \mathrm{pA}, 0.5$ s. D, Average mIPSC frequencies and amplitudes recorded from $\mathrm{PV}^{+}$neurons in NR or BE groups. ${ }^{* *} p<0.001$ (two-way ANOVA). 
resistance (Fig. 5E), action potential threshold (Fig. 5F), and rheobase (Fig. $5 G)$. We further studied membrane excitability of $\mathrm{PV}^{+}$neurons with step-current injections (50-350 pA at an interval of 50 pA) (Fig. 5H). Under NR conditions, deletion of RAR $\alpha$ reduced membrane excitability, indicated by a significant reduction in the number of action potentials in response to current injections (Fig. 5I). After $3 \mathrm{~d}$ of BE, both $\mathrm{RAR}^{\mathrm{fl} /+}$ and $\mathrm{RAR}^{\mathrm{fl} / \mathrm{fl}}$ mice exhibited excitability similar to that of the $\mathrm{RAR}^{\mathrm{fl} / \mathrm{fl}}$ group with NR experience (Fig. 5I). Thus, in addition to synaptic properties, RAR $\alpha$ expression in $\mathrm{PV}^{+}$neurons may also regulate neuronal excitability as an additional mechanism for homeostatic adaptation to reduced overall network activity.

We next recorded basal synaptic transmission from $\mathrm{PV}^{+}$neurons. Similar to observations from PN neurons, no obvious change was observed with mEPSCs in $\mathrm{PV}^{+}$neurons $3 \mathrm{~d}$ after BE (Fig. 6A, B; PV$\operatorname{RAR} \alpha$ het frequency: NR, $13.44 \pm 1.51$ $\mathrm{Hz}$; BE, $10.85 \pm 1.65 \mathrm{~Hz}$; amplitude, NR, $11.18 \pm 0.55 \mathrm{pA} ; \mathrm{BE}, 10.94 \pm 0.47 \mathrm{pA})$. However, BE significantly reduced the frequency of $\mathrm{mIPSC}$ in $\mathrm{PV}^{+}$neurons without changes in amplitude (Fig. $6 C, D$; frequency: NR, $8.59 \pm 0.49 \mathrm{~Hz}$; $\mathrm{BE}, 5.93 \pm 0.42 \mathrm{~Hz}$; amplitude, NR, $29.81 \pm 0.87 \mathrm{pA}$; BE, $28.61 \pm$ $1.00 \mathrm{pA})$. The majority of inhibitory input onto $\mathrm{PV}^{+}$interneurons comes from other $\mathrm{PV}^{+}$interneurons. Indeed, deletion of RAR $\alpha$ from $\mathrm{PV}^{+}$neurons abolished the observed change in mIPSCs in $\mathrm{PV}^{+}$neurons (Fig. $6 C, D$; frequency: NR, $8.06 \pm 0.52$ $\mathrm{Hz}$; BE, $8.01 \pm 0.62 \mathrm{~Hz}$ ). Therefore, the effect of prolonged visual deprivation on mIPSC frequency is similar between PNs and $\mathrm{PV}^{+}$neurons, and RAR $\alpha$ expression in $\mathrm{PV}^{+}$neurons is required to mediate homeostatic changes at the synapses connecting both types of their postsynaptic targets, namely, L2/3 PNs and other $\mathrm{PV}^{+}$neurons.

\section{Fmr1 $\mathrm{KO}$ in $\mathrm{PV}^{+}$neurons blocks effects of visual deprivation and RA}

FMRP, the protein encoded by Fmr1 in mouse and FMR1 in human, is critically involved in synaptic RA signaling. In the absence of FMRP expression, RA-mediated homeostatic synaptic plasticity is completely abolished (Soden and Chen, 2010; Sarti et al., 2013; Z. Zhang et al., 2018). Given the established importance of RAR $\alpha$ expression in BE-induced homeostatic synaptic plasticity at inhibitory synapses in L2/3 PNs, we asked whether FMRP is also required for homeostatic synaptic plasticity in V1m. In the constitutive Fmr1 KO V1m, visual deprivation failed to decrease mIPSC frequency and amplitude in the L2/3 PNs (Fig. 7 $A, B$; frequency: NR, $7.82 \pm 0.32 \mathrm{~Hz}$; BE, $8.35 \pm 0.34 \mathrm{~Hz}$; amplitude: $\mathrm{NR}, 27.70 \pm 0.59 \mathrm{pA} ; \mathrm{BE}, 27.94 \pm 0.78 \mathrm{pA}$ ), whereas the WT controls showed normal homeostatic responses (Fig. $7 A, B$; frequency: NR, $8.39 \pm 0.36 \mathrm{~Hz}$; BE, $5.35 \pm 0.36 \mathrm{~Hz}$; amplitude: NR, $27.25 \pm 1.16 \mathrm{pA}$; BE, $22.61 \pm 0.61 \mathrm{pA})$.

Although FMRP has been shown to be important for RAinduced translational regulation (Soden et al., 2010), it was unclear whether FMRP and RAR $\alpha$ act cell-autonomously within the same neurons. We generated an Fmrl conditional KO mouse by flanking the exon 3 of the Fmrl gene with loxP sites (Fig. 8A).
Deletion of FMRP in $\mathrm{PV}^{+}$neurons was achieved using PV-Cre driver line. Strikingly, selective deletion of FMRP in $\mathrm{PV}^{+}$neurons completely phenocopied the Fmrl constitutive KO (Fig. $8 B, C$; frequency: NR, $7.08 \pm 0.31 \mathrm{~Hz} ; \mathrm{BE}, 6.65 \pm 0.32 \mathrm{~Hz}$; amplitude: NR, $27.87 \pm 0.82 \mathrm{pA}$; BE, $25.92 \pm 0.99 \mathrm{pA}$ ). Our previous work showing that RA synthesis is normal in FMRP KO neurons in hippocampus (Soden and Chen, 2010) supports the possibility that FMRP is involved in homeostatic plasticity at a step downstream of RA synthesis. We thus asked whether, in V1m $\mathrm{PV}^{+}$ neurons, FMRP operates in a similar manner downstream of RA. We found that, in PV-Fmrl cKO mice, RA treatment failed to alter mIPSCs in L2/3 PNs (Fig. 8D, E; frequency: NR, $7.03 \pm 0.32$ $\mathrm{Hz}$; BE, $6.12 \pm 0.26 \mathrm{~Hz}$; amplitude: NR, $30.90 \pm 0.61 \mathrm{pA}$; BE, $30.15 \pm 0.54 \mathrm{pA})$, suggesting that indeed FMRP is required at a step between RA synthesis and final synaptic changes. Together, these results indicate that FMRP and $\operatorname{RAR} \alpha$ act synergistically and cell-autonomously in $\mathrm{PV}^{+}$neurons to enable RA signaling and homeostatic synaptic plasticity.

\section{Discussion}

In this study, we show that RA signaling operates in mouse primary visual cortex and that RAR $\alpha$ expression is critical for homeostatic downregulation of inhibitory synaptic transmission in L2/3 cortical circuit after visual deprivation. Specifically, binocular deprivation mimics the effect of acute RA treatment and causes a reduction in miniature synaptic inhibition onto $\mathrm{L} 2 / 3$ PNs: both require intact RAR $\alpha$ expression in $\mathrm{PV}^{+}$neurons. Interestingly, miniature inhibitory synaptic transmission onto $\mathrm{PV}^{+}$ neurons is affected by visual deprivation in a similar manner and also requires $\operatorname{RAR} \alpha$ expression in $\mathrm{PV}^{+}$neurons. Moreover, FMRP, which has been previously shown to be involved in synaptic RA signaling, is an integral part of the signaling machinery in the V1m circuit. Global or PV-specific deletion of FMRP prevents $\mathrm{BE}$-induced reduction in synaptic inhibition. Together, these data demonstrate the essential role of RA signaling in an in vivo model in a cortical circuit outside of hippocampus, where synaptic RA signaling was initially established. Thus, synaptic RA 
A

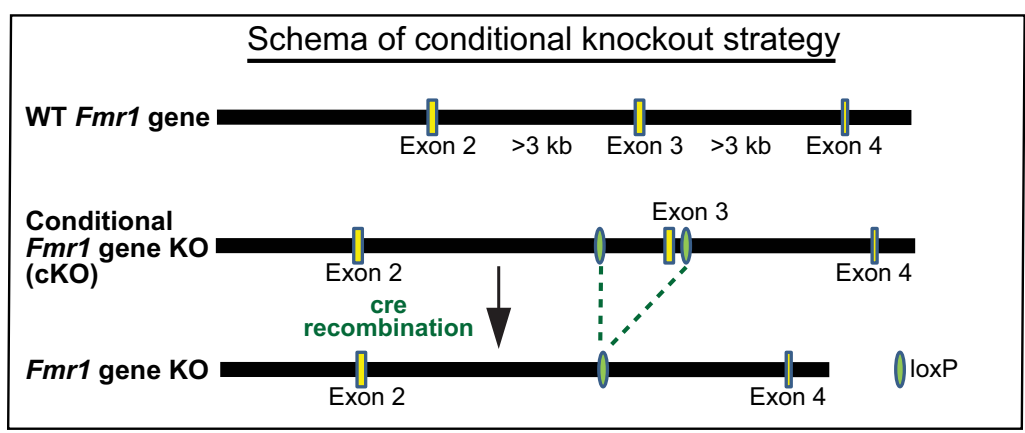

\section{B}

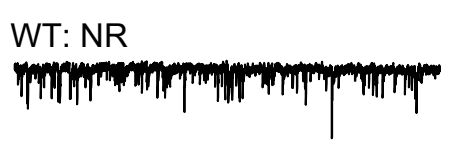

WT: BE

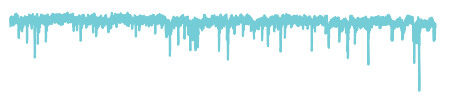

PV-Cre Fmr1 KO: NR

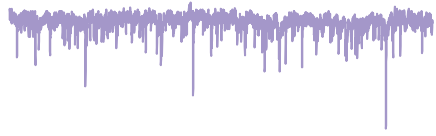

PV-Cre Fmr1 KO: BE

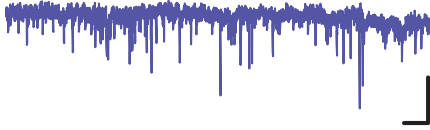

D

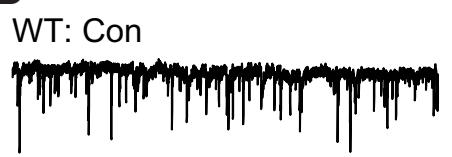

WT: RA

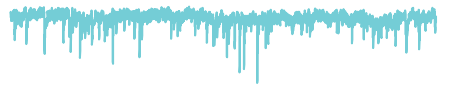

PV-Cre Fmr1 KO: Con

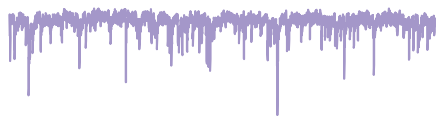

PV-Cre Fmr1 KO: RA

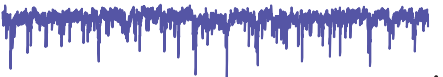

C
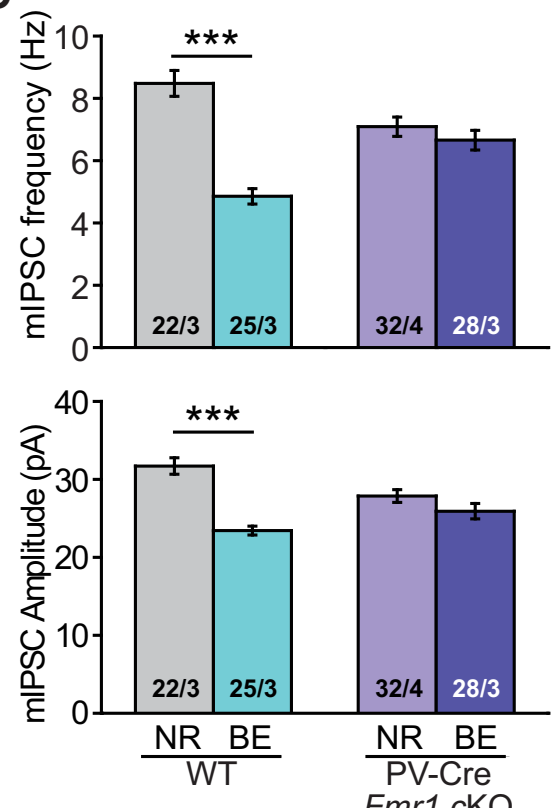

E
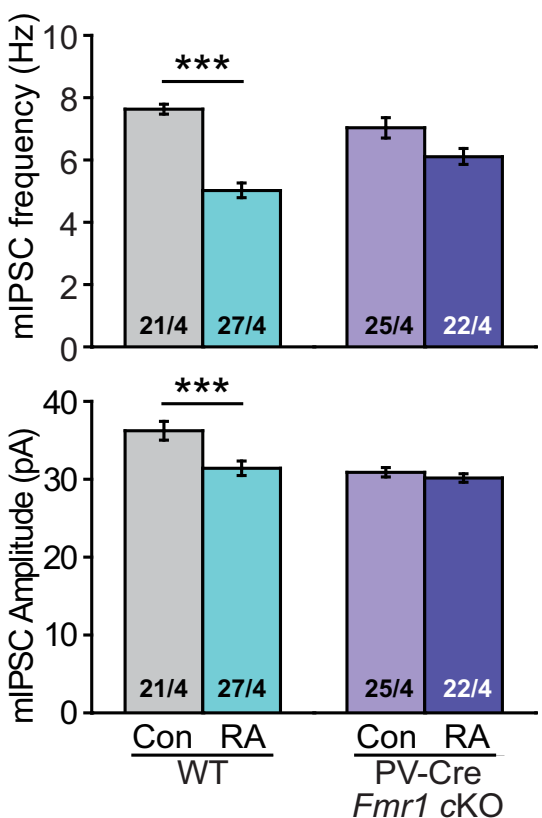

signaling may be a widely adopted molecular mechanism for homeostatic synaptic plasticity throughout the brain.

Visual deprivation is an established and effective protocol to induce homeostatic synaptic plasticity in vivo, and changes at both excitatory and inhibitory synapses have been observed (Whitt et al., 2014; Kaneko and Stryker, 2017). Our findings on the regulation of synaptic inhibition by visual deprivation are consistent with results reported by previous studies performed in postcritical period animals (Keck et al., 2013; Gao et al., 2017). Reduction of mIPSC frequency in L2/3 PNs has been observed $2 \mathrm{~d}$ after retinal lesion (Keck et al., 2013) or after $7 \mathrm{~d}$ of dark rearing (Gao et al., 2017). In addition to these studies focusing on L2/3 circuits, others have also found homeostatic compensation at L4 and L5 circuits, and both synaptic and nonsynaptic changes were observed (Maffei et al., 2004, 2006; Nataraj et al., 2010). Although the exact nature and time course of homeostatic changes vary depending on the specific types of manipulation to achieve visual deprivation (e.g., retinal lesion, dark rearing vs lid suture) (Maffei and Turrigiano, 2008; Whitt et al., 2014), modification of inhibitory synapses and excitatory synapses to readjust synaptic excitation/inhibition balance seems to be a common theme shared by many different sensory manipulations.

Among the many molecular mechanisms identified for homeostatic synaptic plasticity in vitro, several have been shown to play roles in vertebrate in vivo systems. For example, TNF- $\alpha$ is a glial-derived signal that is required for homeostatic operation in vivo at primary sensory cortices and in striatum (Kaneko et al., 2008; Greenhill et al., 2015; Lewitus et al., 2016; Barnes et al., 2017; Teichert et al., 2017). Arc/Arg3.1 has been demonstrated to participate in the homeostatic synaptic plasticity of the excitatory, but not inhibitory, synapses of visual cortex (Gao et al., 2010). Homer 1 a, acting as a molecular integrator of arousal and sleep need via the wake-promoting and sleep-promoting neuromodulators, together with signaling through mGluR1/5, mediates downscaling of excitatory synapses during sleep (Diering et al., 2017). RA, as a newly identified molecular player for synaptic plas-

Figure 8. Selective deletion of FMRP in $\mathrm{PV}^{+}$neurons prevents modulation of synaptic inhibition induced by BE or RA treatment. $\boldsymbol{A}$, Schematic diagram showing the strategy for generating the $F m r 1$ conditional $\mathrm{KO}$ mice. $\boldsymbol{B}$, Representative traces from L2/3 PNs of PV-Fmr1 CKO mice (PV-Cre, Fmr1 CKO) and WT littermate controls under NR or BE conditions. Calibration: 50 pA, 0.5 s. C, Quantification of mIPSC frequencies and amplitudes from L2/3 PNs of WT and PV-Fmr 1 cKO mice. ${ }^{* * *} p<0.001$ (two-way ANOVA). D, Example traces from L2/3 PNs of PV-Fmr1 CKO mice and WT littermate controls after RA or vehicle treatment. Calibration: $50 \mathrm{pA}$

0.5 s. $E_{,}$Quantification of mIPSC frequencies and amplitudes from L2/3 PNs of WT and PV-Fmr1 CKO mice after treatment with RA or vehicle control. ${ }^{* * *} p<0.001$ (two-way ANOVA). 
ticity, was shown to mediate homeostatic synaptic plasticity in response to pharmacological blockade of excitatory synaptic activity in hippocampal principle neurons from primary and slice cultures (Aoto et al., 2008; Sarti et al., 2013). In this study, we made three important conceptual advancements from our original studies. First, we show that RA operates in a cortical circuit, thus demonstrating that synaptic RA signaling is not a hippocampal-specific phenomenon but may likely be a widely present signaling mechanism in multiple regions of the brain. Second, using an in vivo homeostatic plasticity model, we show that synaptic RA signaling is essential for visual deprivation-induced synaptic compensation at inhibitory synapses in the visual cortex, thus establishing its in vivo relevance and significance. Third, we found unexpectedly that visual cortical homeostatic synaptic plasticity hinges on RAR $\alpha$ expression in $\mathrm{PV}^{+}$interneurons, thus extending the neuronal types in which RA signaling may be functioning.

As one of the most important inhibitory neurons, $\mathrm{PV}^{+}$neurons primarily target soma and/or perisomatic regions (Markram et al., 2004) and participate in diverse categories of visual function, including feature selectivity and perceptual discrimination (Runyan et al., 2010; Lee et al., 2012). Therefore, modulation of GABAergic synapses from $\mathrm{PV}^{+}$neurons is likely to cause a significant impact on the functional output of $\mathrm{PV}^{+}$target neurons. The discovery that PV-mediated inhibition onto PNs and other $\mathrm{PV}^{+}$neurons are both modified by BE is somewhat unexpected; it suggests that visual deprivation impacts neuronal activity of both excitatory and inhibitory neurons, and that homeostatic changes in cortical circuits preserve both cortical responsiveness to sensory input and excitation/inhibition balance of local network. Given that $\mathrm{PV}^{+}$neuron is the common presynaptic partner for both the PNs and $\mathrm{PV}^{+}$neurons examined, and that RAR $\alpha$ expression in $\mathrm{PV}^{+}$neurons instead of PNs is required for the observed homeostatic synaptic plasticity, it is likely that RA signaling, in this context, operates in the presynaptic compartment, which is different from its action in the hippocampal PNs. Our previous studies show that $\operatorname{RAR} \alpha$ regulates local protein synthesis in dendrites, which underlies most of its action postsynaptically (Aoto et al., 2008; Poon and Chen, 2008). Local protein synthesis in axonal compartments of mature neurons was traditionally thought unlikely due to lack of apparent translational machineries observed in axons. However, recent evidence indicates that ribosomes are present in axon terminals, and local protein synthesis could indeed occur in presynaptic terminals and is required for long-term plasticity of GABA release (Younts et al., 2016). Given our limited knowledge on the mRNA substrates whose translation is regulated by $\operatorname{RAR} \alpha$ (Poon and Chen, 2008), the exact molecular details of presynaptic action of RA warrants further investigation in a future study.

The connection between FMRP and RA/RAR $\alpha$ signaling was first suggested when RA- and synaptic inactivity (TTX + APV treatment)-induced local protein synthesis occur in dendritic RNA granules enriched with both FMRP and RAR $\alpha$ (Maghsoodi et al., 2008). In the Fmr1 KO hippocampal neurons, RA signaling and RA-mediated homeostatic synaptic plasticity are absent from both excitatory and inhibitory synapses (Soden and Chen, 2010; Sarti et al., 2013), supporting the notion that RA signals through an FMRP-dependent mechanism. Importantly, deficient RA signaling is also found in human neurons derived from FXS patient iPS cells (Z. Zhang et al., 2018), indicating that the functional link between FMRP and RA signaling is conserved across different mammalian species. In this study, we further explored the involvement of FMRP in RA-dependent homeostatic synaptic plas- ticity in cortical circuits and found that $\mathrm{PV}^{+}$interneurons are the converging loci in which both FMRP and RAR $\alpha$ expression is essential for normal homeostatic plasticity and synaptic RA signaling at inhibitory synapses onto L2/3 PNs. Inappropriate excitation/inhibition balance has been found as a major network phenotype at multiple circuits of the FXS and autism spectrum disorders brain (Gogolla et al., 2009; Contractor et al., 2015; Nelson and Valakh, 2015). Thus, in addition to altered Hebbian plasticity (i.e., mGluR-dependent LTD) (Huber et al., 2002; Li et al., 2002; Larson et al., 2005), impaired homeostatic synaptic plasticity in both hippocampal and cortical circuits may exacerbate network instability in FXS, which has severe consequence in information processing and cognitive functions (Eichler and Meier, 2008; Nelson and Valakh, 2015).

In conclusion, our study shows that RA signaling plays a critical role in homeostatic plasticity elicited in an in vivo setting, and that inhibitory synapses are one of the major loci regulated by sensory experience. Findings from this study raise more questions. How does RA operate in presynaptic neurons to regulate synaptic transmission? Is such presynaptic action specific to $\mathrm{PV}^{+}$ inhibitory interneurons? What is the molecular nature of the interaction between FMRP and RAR $\alpha$, and does sensory experience/synaptic activity modulate such interaction? Is there structural plasticity accompanying synaptic changes following RA signaling? Understanding these questions will help generate a general picture of RA signaling in the brain and provide further insight into its functional significance in homeostatic plasticity, information processing in cortical and subcortical circuits, and eventually, cognitive functions.

\section{References}

Aoto J, Nam CI, Poon MM, Ting P, Chen L (2008) Synaptic signaling by all-trans retinoic acid in homeostatic synaptic plasticity. Neuron 60:308320. CrossRef Medline

Arendt KL, Zhang Y, Jurado S, Malenka RC, Südhof TC, Chen L (2015a) Retinoic acid and LTP recruit postsynaptic AMPA receptors using distinct SNARE-dependent mechanisms. Neuron 86:442-456. CrossRef Medline Arendt KL, Zhang Z, Ganesan S, Hintze M, Shin MM, Tang Y, Cho A, Graef IA, Chen L (2015b) Calcineurin mediates homeostatic synaptic plasticity by regulating retinoic acid synthesis. Proc Natl Acad Sci U S A 112: E5744-E5752. CrossRef Medline

Barnes SJ, Franzoni E, Jacobsen RI, Erdelyi F, Szabo G, Clopath C, Keller GB, and Keck T (2017) Deprivation-induced homeostatic spine scaling in vivo is localized to dendritic branches that have undergone recent spine loss. Neuron 96:871-882.e5. CrossRef Medline

Blackman MP, Djukic B, Nelson SB, Turrigiano GG (2012) A critical and cell-autonomous role for MeCP2 in synaptic scaling up. J Neurosci 32: 13529-13536. CrossRef Medline

Chapellier B, Mark M, Garnier JM, LeMeur M, Chambon P, Ghyselinck NB (2002) A conditional floxed (loxP-flanked) allele for the retinoic acid receptor alpha (RARalpha) gene. Genesis 32:87-90. CrossRef Medline

Chen L, Lau AG, Sarti F (2014) Synaptic retinoic acid signaling and homeostatic synaptic plasticity. Neuropharmacology 78:3-12. CrossRef Medline

Contractor A, Klyachko VA, Portera-Cailliau C (2015) Altered neuronal and circuit excitability in fragile $\mathrm{X}$ syndrome. Neuron 87:699-715. CrossRef Medline

Desai NS, Cudmore RH, Nelson SB, Turrigiano GG (2002) Critical periods for experience-dependent synaptic scaling in visual cortex. Nat Neurosci 5:783-789. CrossRef Medline

Diering GH, Nirujogi RS, Roth RH, Worley PF, Pandey A, Huganir RL (2017) Homerla drives homeostatic scaling-down of excitatory synapses during sleep. Science 355:511-515. CrossRef Medline

Duprey-Díaz MV, Blagburn JM, Blanco RE (2016) Optic nerve injury upregulates retinoic acid signaling in the adult frog visual system. J Chem Neuroanat 77:80-92. CrossRef Medline

Eichler SA, Meier JC (2008) E-I balance and human diseases: from molecules to networking. Front Mol Neurosci 1:2. CrossRef Medline 
Feldman DE (2009) Synaptic mechanisms for plasticity in neocortex. Annu Rev Neurosci 32:33-55. CrossRef Medline

Frenkel MY, Bear MF (2004) How monocular deprivation shifts ocular dominance in visual cortex of young mice. Neuron 44:917-923. CrossRef Medline

Gao M, Sossa K, Song L, Errington L, Cummings L, Hwang H, Kuhl D, Worley P, Lee HK (2010) A specific requirement of Arc/Arg3.1 for visual experience-induced homeostatic synaptic plasticity in mouse primary visual cortex. J Neurosci 30:7168-7178. CrossRef Medline

Gao M, Whitt JL, Huang S, Lee A, Mihalas S, Kirkwood A, Lee HK (2017) Experience-dependent homeostasis of 'noise' at inhibitory synapses preserves information coding in adult visual cortex. Philos Trans R Soc Lond B Biol Sci 372:20160156. CrossRef Medline

Goel A, Lee HK (2007) Persistence of experience-induced homeostatic synaptic plasticity through adulthood in superficial layers of mouse visual cortex. J Neurosci 27:6692-6700. CrossRef Medline

Gogolla N, Leblanc JJ, Quast KB, Südhof TC, Fagiolini M, Hensch TK (2009) Common circuit defect of excitatory-inhibitory balance in mouse models of autism. J Neurodev Disord 1:172-181. CrossRef Medline

Gordon JA, Stryker MP (1996) Experience-dependent plasticity of binocular responses in the primary visual cortex of the mouse. J Neurosci 16: 3274-3286. CrossRef Medline

Greenhill SD, Ranson A, Fox K (2015) Hebbian and homeostatic plasticity mechanisms in regular spiking and intrinsic bursting cells of cortical layer 5. Neuron 88:539-552. CrossRef Medline

Hammad M, Schmidt SL, Zhang X, Bray R, Frohlich F, Ghashghaei HT (2015) Transplantation of GABAergic interneurons into the neonatal primary visual cortex reduces absence seizures in stargazer mice. Cereb Cortex 25:2970-2979. CrossRef Medline

He HY, Ray B, Dennis K, Quinlan EM (2007) Experience-dependent recovery of vision following chronic deprivation amblyopia. Nat Neurosci 10: 1134-1136. CrossRef Medline

He K, Petrus E, Gammon N, Lee HK (2012) Distinct sensory requirements for unimodal and cross-modal homeostatic synaptic plasticity. J Neurosci 32:8469-8474. CrossRef Medline

Hensch TK, Fagiolini M, Mataga N, Stryker MP, Baekkeskov S, Kash SF (1998) Local GABA circuit control of experience-dependent plasticity in developing visual cortex. Science 282:1504-1508. CrossRef Medline

Hu JH, Park JM, Park S, Xiao B, Dehoff MH, Kim S, Hayashi T, Schwarz MK, Huganir RL, Seeburg PH, Linden DJ, Worley PF (2010) Homeostatic scaling requires group I mGluR activation mediated by Homer 1 a. Neuron 68:1128-1142. CrossRef Medline

Huber KM, Gallagher SM, Warren ST, Bear MF (2002) Altered synaptic plasticity in a mouse model of fragile X mental retardation. Proc Natl Acad Sci U S A 99:7746-7750. CrossRef Medline

Ibata K, Sun Q, Turrigiano GG (2008) Rapid synaptic scaling induced by changes in postsynaptic firing. Neuron 57:819-826. CrossRef Medline

Jakawich SK, Nasser HB, Strong MJ, McCartney AJ, Perez AS, Rakesh N, Carruthers CJ, Sutton MA (2010) Local presynaptic activity gates homeostatic changes in presynaptic function driven by dendritic BDNF synthesis. Neuron 68:1143-1158. CrossRef Medline

Kaeser PS, Deng L, Wang Y, Dulubova I, Liu X, Rizo J, Südhof TC (2011) RIM proteins tether $\mathrm{Ca}^{2+}$ channels to presynaptic active zones via a direct PDZ-domain interaction. Cell 144:282-295. CrossRef Medline

Kaneko M, Stellwagen D, Malenka RC, Stryker MP (2008) Tumor necrosis factor-alpha mediates one component of competitive, experiencedependent plasticity in developing visual cortex. Neuron 58:673-680. CrossRef Medline

Kaneko M, Stryker MP (2017) Homeostatic plasticity mechanisms in mouse V1. Philos Trans R Soc Lond B Biol Sci 372:20160156. CrossRef Medline

Kavalali ET, Monteggia LM (2015) How does ketamine elicit a rapid antidepressant response? Curr Opin Pharmacol 20:35-39. CrossRef Medline

Keck T, Keller GB, Jacobsen RI, Eysel UT, Bonhoeffer T, Hübener M (2013) Synaptic scaling and homeostatic plasticity in the mouse visual cortex in vivo. Neuron 80:327-334. CrossRef Medline

Kim S, Ziff EB (2014) Calcineurin mediates synaptic scaling via synaptic trafficking of $\mathrm{Ca}^{2+}$-permeable AMPA receptors. PLoS Biol 12:e1001900. CrossRef Medline

Larson J, Jessen RE, Kim D, Fine AK, du Hoffmann J (2005) Age-dependent and selective impairment of long-term potentiation in the anterior piri- form cortex of mice lacking the fragile $\mathrm{X}$ mental retardation protein. J Neurosci 25:9460-9469. CrossRef Medline

Lee HK, Whitt JL (2015) Cross-modal synaptic plasticity in adult primary sensory cortices. Curr Opin Neurobiol 35:119-126. CrossRef Medline

Lee SH, Kwan AC, Zhang S, Phoumthipphavong V, Flannery JG, Masmanidis SC, Taniguchi H, Huang ZJ, Zhang F, Boyden ES, Deisseroth K, Dan Y (2012) Activation of specific interneurons improves V1 feature selectivity and visual perception. Nature 488:379-383. CrossRef Medline

Lewitus GM, Konefal SC, Greenhalgh AD, Pribiag H, Augereau K, Stellwagen D (2016) Microglial TNF-alpha suppresses cocaine-induced plasticity and behavioral sensitization. Neuron 90:483-491. CrossRef Medline

Li J, Pelletier MR, Perez Velazquez JL, Carlen PL (2002) Reduced cortical synaptic plasticity and GluR1 expression associated with fragile X mental retardation protein deficiency. Mol Cell Neurosci 19:138-151. CrossRef Medline

Madisen L, Zwingman TA, Sunkin SM, Oh SW, Zariwala HA, Gu H, Ng LL, Palmiter RD, Hawrylycz MJ, Jones AR, Lein ES, Zeng H (2010) A robust and high-throughput cre reporting and characterization system for the whole mouse brain. Nat Neurosci 13:133-140. CrossRef Medline

Maffei A, Turrigiano GG (2008) Multiple modes of network homeostasis in visual cortical layer 2/3. J Neurosci 28:4377-4384. CrossRef Medline

Maffei A, Nelson SB, Turrigiano GG (2004) Selective reconfiguration of layer 4 visual cortical circuitry by visual deprivation. Nat Neurosci 7:1353-1359. CrossRef Medline

Maffei A, Nataraj K, Nelson SB, Turrigiano GG (2006) Potentiation of cortical inhibition by visual deprivation. Nature 443:81-84. CrossRef Medline

Maghsoodi B, Poon MM, Nam CI, Aoto J, Ting P, Chen L (2008) Retinoic acid regulates RARalpha-mediated control of translation in dendritic RNA granules during homeostatic synaptic plasticity. Proc Natl Acad Sci U S A 105:16015-16020. CrossRef Medline

Markram H, Toledo-Rodriguez M, Wang Y, Gupta A, Silberberg G, Wu C (2004) Interneurons of the neocortical inhibitory system. Nat Rev Neurosci 5:793-807. CrossRef Medline

Nataraj K, Le Roux N, Nahmani M, Lefort S, Turrigiano G (2010) Visual deprivation suppresses L5 pyramidal neuron excitability by preventing the induction of intrinsic plasticity. Neuron 68:750-762. CrossRef Medline

Nelson SB, Valakh V (2015) Excitatory/inhibitory balance and circuit homeostasis in autism spectrum disorders. Neuron 87:684-698. CrossRef Medline

O’Brien RJ, Kamboj S, Ehlers MD, Rosen KR, Fischbach GD, Huganir RL (1998) Activity-dependent modulation of synaptic AMPA receptor accumulation. Neuron 21:1067-1078. CrossRef Medline

Park E, Tjia M, Zuo Y, Chen L (2018) Postnatal ablation of synaptic retinoic acid signaling impairs cortical information processing and sensory discrimination in mice. J Neurosci 38:5277-5288. CrossRef Medline

Pfeffer CK, Xue M, He M, Huang ZJ, Scanziani M (2013) Inhibition of inhibition in visual cortex: the logic of connections between molecularly distinct interneurons. Nat Neurosci 16:1068-1076. CrossRef Medline

Poon MM, Chen L (2008) Retinoic acid-gated sequence-specific translational control by RARalpha. Proc Natl Acad Sci U S A 105:20303-20308. CrossRef Medline

Qiu Z, Sylwestrak EL, Lieberman DN, Zhang Y, Liu XY, Ghosh A (2012) The Rett syndrome protein MeCP2 regulates synaptic scaling. J Neurosci 32: 989-994. CrossRef Medline

Runyan CA, Schummers J, Van Wart A, Kuhlman SJ, Wilson NR, Huang ZJ, Sur M (2010) Response features of parvalbumin-expressing interneurons suggest precise roles for subtypes of inhibition in visual cortex. Neuron 67:847-857. CrossRef Medline

Sarti F, Schroeder J, Aoto J, Chen L (2012) Conditional RARalpha knockout mice reveal acute requirement for retinoic acid and RARalpha in homeostatic plasticity. Front Mol Neurosci 5:16. CrossRef Medline

Sarti F, Zhang Z, Schroeder J, Chen L (2013) Rapid suppression of inhibitory synaptic transmission by retinoic acid. J Neurosci 33:11440-11450. CrossRef Medline

Shepherd JD, Rumbaugh G, Wu J, Chowdhury S, Plath N, Kuhl D, Huganir RL, Worley PF (2006) Arc/Arg3.1 mediates homeostatic synaptic scaling of AMPA receptors. Neuron 52:475-484. CrossRef Medline

Soden ME, Chen L (2010) Fragile X protein FMRP is required for homeostatic plasticity and regulation of synaptic strength by retinoic acid. J Neurosci 30:16910-16921. CrossRef Medline 
Stellwagen D, Malenka RC (2006) Synaptic scaling mediated by glial TNFalpha. Nature 440:1054-1059. CrossRef Medline

Teichert M, Liebmann L, Hübner CA, Bolz J (2017) Homeostatic plasticity and synaptic scaling in the adult mouse auditory cortex. Sci Rep 7:17423. CrossRef Medline

Thiagarajan TC, Piedras-Renteria ES, Tsien RW (2002) Alpha- and betaCaMKII: inverse regulation by neuronal activity and opposing effects on synaptic strength. Neuron 36:1103-1114. CrossRef Medline

Turrigiano G (2012) Homeostatic synaptic plasticity: local and global mechanisms for stabilizing neuronal function. Cold Spring Harb Perspect Biol 4:a005736. CrossRef Medline

Turrigiano G, Abbott LF, Marder E (1994) Activity-dependent changes in the intrinsic properties of cultured neurons. Science 264:974-977. CrossRef Medline

Turrigiano G, Leslie KR, Desai NS, Rutherford LC, Nelson SB (1998) Activity-dependent scaling of quantal amplitude in neocortical neurons. Nature 391:892-896. CrossRef Medline

Wang HL, Zhang Z, Hintze M, Chen L (2011) Decrease in calcium concentration triggers neuronal retinoic acid synthesis during homeostatic synaptic plasticity. J Neurosci 31:17764-17771. CrossRef Medline

Whitt JL, Petrus E, Lee HK (2014) Experience-dependent homeostatic synaptic plasticity in neocortex. Neuropharmacology 78:45-54. CrossRef Medline
Wiesel TN, Hubel DH (1963) Single-cell responses in striate cortex of kittens deprived of vision in one eye. J Neurophysiol 26:1003-1017. CrossRef Medline

Wiesel TN, Hubel DH (1965) Comparison of the effects of unilateral and bilateral eye closure on cortical unit responses in kittens. J Neurophysiol 28:1029-1040. CrossRef Medline

Yee AX, Chen L (2016) Differential regulation of spontaneous and evoked inhibitory synaptic transmission in somatosensory cortex by retinoic acid. Synapse 70:445-452. CrossRef Medline

Younts TJ, Monday HR, Dudok B, Klein ME, Jordan BA, Katona I, Castillo PE (2016) Presynaptic protein synthesis is required for long-term plasticity of GABA release. Neuron 92:479-492. CrossRef Medline

Yu LM, Goda Y (2009) Dendritic signalling and homeostatic adaptation. Curr Opin Neurobiol 19:327-335. CrossRef Medline

Zhang J, Ackman JB, Xu HP, Crair MC (2011) Visual map development depends on the temporal pattern of binocular activity in mice. Nat Neurosci 15:298-307. CrossRef Medline

Zhang Z, Marro SG, Zhang Y, Arendt KL, Patzke C, Zhou B, Fair T, Yang N, Südhof TC, Wernig M, Chen L (2018) The fragile X mutation impairs homeostatic plasticity in human neurons by blocking synaptic retinoic acid signaling. Sci Transl Med 10:eaar4338. CrossRef Medline 